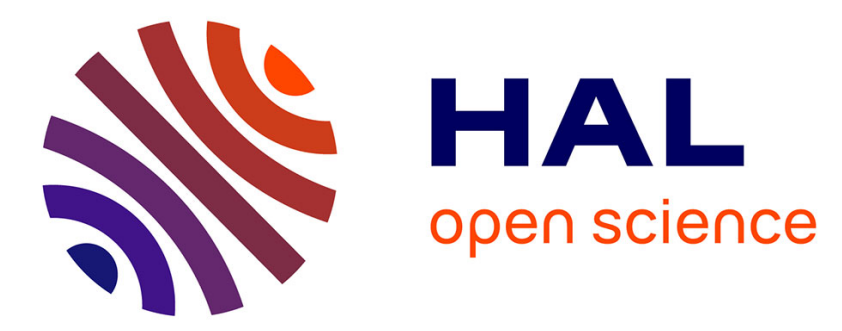

\title{
Impact of Continental Freshwater Runoff on Coastal Sea Level
}

Fabien Durand, Christopher Piecuch, Melanie Becker, Fabrice Papa, Sherin Raju, Jamal Khan, Rui Ponte

\section{> To cite this version:}

Fabien Durand, Christopher Piecuch, Melanie Becker, Fabrice Papa, Sherin Raju, et al.. Impact of Continental Freshwater Runoff on Coastal Sea Level. Surveys in Geophysics, 2019, 10.1007/s10712019-09536-w . hal-02142102

\section{HAL Id: hal-02142102 \\ https://hal-univ-rochelle.archives-ouvertes.fr/hal-02142102}

Submitted on 7 Jul 2020

HAL is a multi-disciplinary open access archive for the deposit and dissemination of scientific research documents, whether they are published or not. The documents may come from teaching and research institutions in France or abroad, or from public or private research centers.
L'archive ouverte pluridisciplinaire HAL, est destinée au dépôt et à la diffusion de documents scientifiques de niveau recherche, publiés ou non, émanant des établissements d'enseignement et de recherche français ou étrangers, des laboratoires publics ou privés. 


\title{
Impact of Continental Freshwater Runoff on Coastal Sea Level
}

\author{
Fabien Durand ${ }^{1}$ (D) . Christopher G. Piecuch ${ }^{2} \cdot$ Mélanie Becker $^{3} \cdot$ Fabrice Papa ${ }^{1}$. \\ Sherin V. Raju ${ }^{4}$ Jamal U. Khan ${ }^{1,5} \cdot$ Rui M. Ponte ${ }^{6}$
}

Received: 13 December 2018 / Accepted: 23 April 2019

(c) Springer Nature B.V. 2019

\begin{abstract}
Freshwater discharge to the coastal ocean is a fundamental component of the global water cycle. It can impact coastal sea level over a broad range of spatial and temporal scales. Here we review the status of the current knowledge based on observational and modeling approaches. The main limitation in studies of the influence of rivers on coastal sea level has been the lack of consolidated discharge databases. We first provide an inventory of the main data sources currently available. We then review the existing knowledge about the runoff forcing of coastal sea level, differentiating between the mass and steric height contributions. Both mechanisms are important for coastal sea level budget, although they act on different scales. The mass contribution is related to a global ocean response that is established on relatively short timescales through barotropic processes while the steric contribution is associated with more of a regional adjustment that takes place on longer timescales by means of baroclinic dynamics. While numerical models required to simulate the runoff impact on coastal sea level variability have been improving over the past decades, a similar evolution is awaited for observational techniques, both for in situ observation and for remote sensing.
\end{abstract}

Keywords Sea level $\cdot$ Runoff $\cdot$ Discharge $\cdot$ River plumes $\cdot$ Salinity

Fabien Durand

fabien.durand@ird.fr

1 LEGOS, Université de Toulouse, CNES, CNRS, IRD, UPS, 14 Avenue Edouard Belin, 31400 Toulouse, France

2 Woods Hole Oceanographic Institution, MS\#21, Woods Hole, MA 02543-1050, USA

3 LIENSs, Université de La Rochelle, CNRS, 2 rue Olympe de Gouges, 17000 La Rochelle, France

4 Indo-French Cell for Water Sciences, Indian Institute of Science, Bangalore 560 012, India

5 Institute of Water and Flood Management, Bangladesh University of Engineering and Technology, Dhaka, Bangladesh

6 Atmospheric and Environmental Research, Inc., 131 Hartwell Avenue, Lexington, MA 02421-3126, USA 


\section{Introduction}

\subsection{Geographical and temporal scope}

Continental freshwater runoff or discharge is a major constituent of the climatic system. Indeed, it represents a key component of the global water cycle (Trenberth et al. 2007). River discharge returns back to the ocean water that partly comes from evaporation over the oceans and was precipitated over continents, thereby maintaining a long-term balance of freshwater in the oceans. Rivers also play an important role in global biogeochemical cycles, discharging large amounts of sediment and nutrients to the oceans (Dai et al. 2009). In the present study, we review the current knowledge about the influence of river discharge on coastal sea level, focusing on large river deltas and large estuaries with strong outflows, and specifically on the best documented systems with some of the world's largest discharges (e.g., Amazon, Ganges-Brahmaputra-Meghna, Yangtze). Several other river outflows, although weaker in terms of overall discharge but extensively studied in recent years, will also be presented. We restrict our review to the regions dynamically connected to the ocean, which means that the upstream parts of the estuaries and deltas, under the primary influence of riverine hydraulics in terms of water level, are left out of our review. We focus our review on long timescales, typically seasonal scales and longer.

\subsection{Why Should We Care About Runoff?}

The coastal zone is a dynamic interface, where the rivers, land, and ocean interact. Throughout history, these regions have been attractive for humans due to their extremely rich resources (subsistence, ecologic, economic, logistic, recreative). In the year 2000, more than $10 \%$ of the world's population (625 million) lived in low-lying coastal areas located at less than 10 metres above sea level (Neumann et al. 2015). In these regions, very large numbers of people are particularly vulnerable to sea level rise, storm surge, natural and/or anthropogenic land subsidence, and variability of the sediment transports. This vulnerability is aggravated for low-lying deltaic regions, with large rivers and population densities among the highest of the world, such as the delta systems of Ganges-Brahmaputra, Mekong, Yangtze and Niger, to name a few (Fig. 1; Becker et al. 2019). Moreover, many of the world's megacities are located in the coastal zone and many of these are situated in large deltas. In this regard, Asia stands out as a prominent zone of vulnerability (Dhaka, Kolkata, Shanghai, Ho Chi Minh City, Bangkok; Fig. 2).

In deltaic and estuarine areas, a large river runoff can induce sea level fluctuations at the river mouths on a variety of timescales, acting in concert with other environmental factors, and making their interpretation more complex (Meade and Emery 1971). Although this issue is important for a better understanding of coastal zone vulnerability, the contribution of river runoff to sea level fluctuations has received little attention (e.g., Meade and Emery 1971; Aubrey et al. 1988; Tsimplis and Woodworth 1994; Piecuch et al. 2018). The typical magnitude of regional sea level variability induced by river runoff can be of the order of 1-10 cm for the largest discharges (Piecuch et al. 2018). This implies that runoff has a significant contribution to the overall sea level budget, in the regions under the influence of continental discharge, at our timescales of interest. Quantifying those impacts is of great interest to oceanographic and climate studies. Therefore, there is now a widespread need 


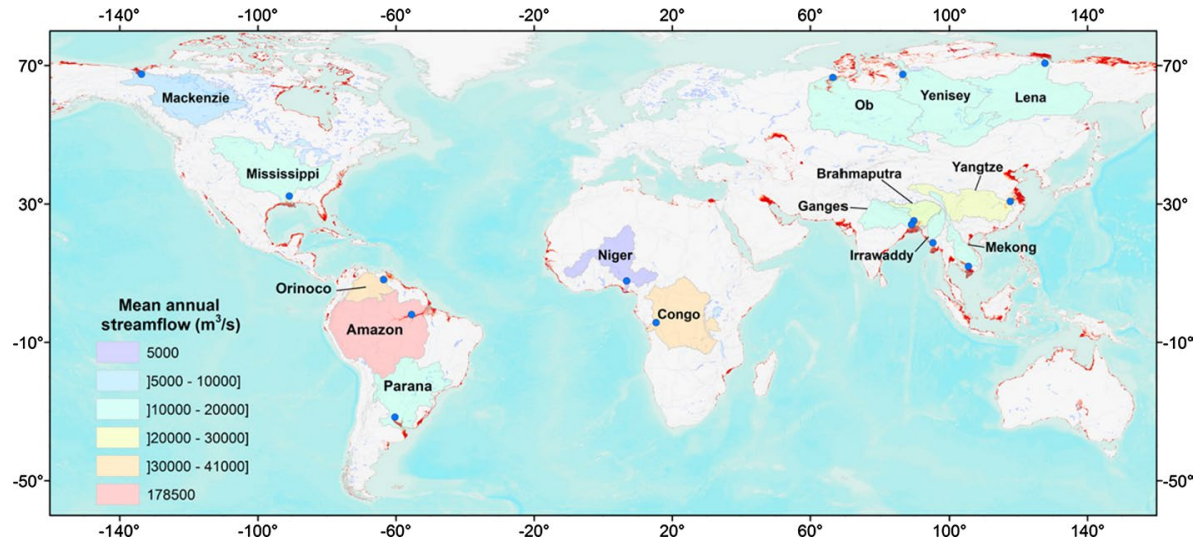

Fig. 1 Major river basins of the world (listed in Table 1). The global digital elevation model GTOPO30 (lta.cr.usgs.gov/GTOPO30) is used to map elevation less than 10 meters (in red). The blue dots locate the Global Runoff Data Center (GRDC, 2014, 2018) gauge stations listed in Table 1. The color of the basins represents their mean annual streamflow $\left(\mathrm{m}^{3} / \mathrm{s}\right)$

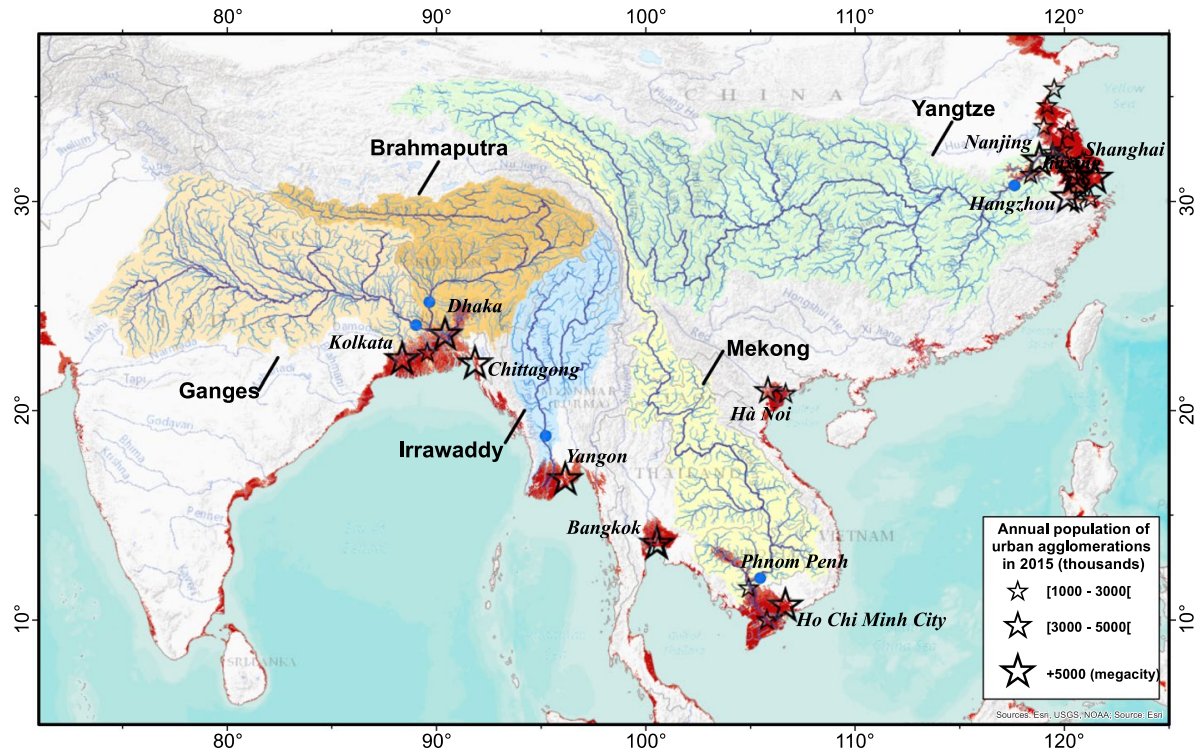

Fig. 2 Major Asian deltas. The global digital elevation model GTOPO30 (lta.cr.usgs.gov/GTOPO30) is used to map elevation less than 10 meters (in red). The stream network is provided by Hydrological data and maps based on SHuttle Elevation Derivatives at multiple Scales (HydroSHEDS, hydrosheds.cr.usgs. gov/hydro.php). The blue dots locate the Global Runoff Data Center (GRDC, 2014, 2018) gauge stations listed in Table 1. The stars correspond to large urban agglomerations with 1 million inhabitants or more in 2015 (from United Nations world urbanization prospects: The 2014 Revision, esa.un.org/unpd/wup/cdRom/) 
for access to comprehensive continental discharge estimates globally. An up-to-date inventory of the available estimates will be presented in Sect. 2.

\subsection{Processes and associated space/timescales}

Primarily, one can think of two different means for riverine water to influence sea level. This can be understood from the following equation, which presents the breakdown of hydrostatic sea level into its steric, bottom pressure and atmospheric components (see for instance Gill and Niller 1973) for full details):

$$
\eta=\frac{P_{b}^{\prime}}{g \rho_{0}}-\frac{1}{\rho_{0}} \int_{-H}^{0} \rho^{\prime} d z+\frac{P_{a t m}}{g \rho_{0}}
$$

where $\eta$ represents the deviation of sea level around its mean, $g$ is the acceleration of gravity, $P_{b}^{\prime}$ is the deviation of ocean bottom pressure, $\rho_{0}$ is a representative (constant) seawater density, $H$ is the ocean depth, $\rho^{\prime}$ is the deviation of seawater density around its mean, $P_{a t m}$ is the deviation of atmospheric pressure. In the present study we do not consider the effects of atmospheric pressure on sea level variability (cf. Piecuch et al. 2019). Henceforth, we will consider only the first two terms, reflecting the two effects known as the ocean mass contribution and the steric effect, respectively.

The first effect is the ocean mass contribution (termed as "manometric sea level" by Gregory et al., this issue), which has received relatively little attention (Dobslaw and Thomas 2007). All else being equal, freshwater discharged into the sea increases the total water mass and volume of the global ocean, hence raising the global-mean sea level. Excluding any other forcing, basic physical intuition suggests that the oceanic adjustment to surface mass loading occurs rapidly, similar to what happens under atmospheric pressure loading (Ponte 1993). Facilitated by barotropic waves, equilibrium is reached on the order of days, resulting in an isostatic response on longer timescales; mass is redistributed and spread evenly over the global ocean surface such that there are negligible horizontal pressure gradients (e.g., Ponte 2006). This basic reasoning ignores complicating factors like coasts, topography, and stratification, which can effect resonances and other nonequilibrium responses (Dobslaw and Thomas 2007), as in the response to other ocean surface loading (Ponte 1993, 2006). One of the pending questions for the scientific community regards the detailed dynamics of the transient barotropic adjustments that are triggered by river outflows and whether significant nonequilibrium responses are possible.

Given the global ocean's relatively large surface area, one might anticipate that freshwater discharged into the ocean by rivers has a negligible influence on globally averaged sea level. However, this is not necessarily the case. Figure 3 shows the freshwater volume discharged by the Amazon River observed at Óbidos (Brazil) during 1993-2010, converted to units of equivalent global-mean sea level. That is, the river discharge time series has been integrated in time and divided by the global ocean's surface area. For comparison, the contemporaneous global-mean sea level time series from satellite altimetry is also shown. To emphasize low-frequency (interannual) variation, linear trends and seasonal cycles were removed from both time series, and a 13-month low-pass filter was applied. The standard deviation computed from the Amazon River time series is $0.4 \mathrm{~mm}$, which is not small compared to the standard deviation of $1.0 \mathrm{~mm}$ calculated 


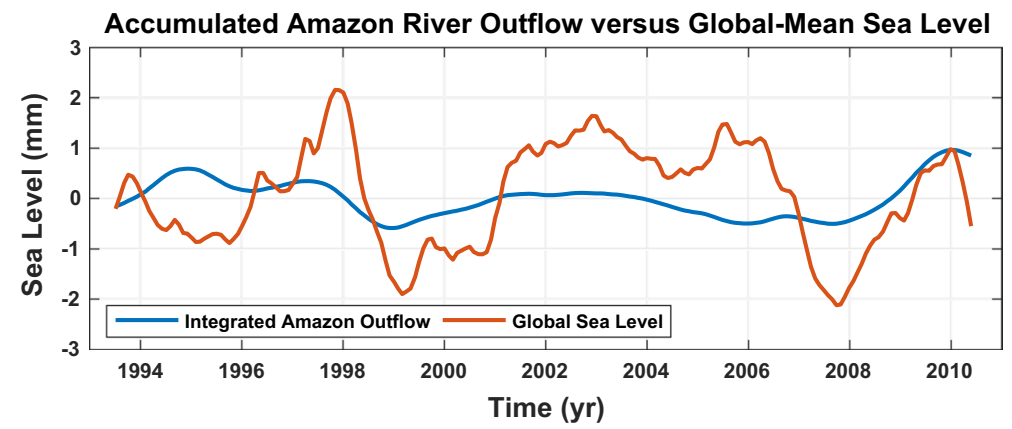

Fig. 3 Comparison of accumulated Amazon River outflow and global-mean sea level. Blue curve is the time integral of monthly discharge from the Amazon River observed at Óbidos (Brazil) from the database of Dai (2016) and normalized by global ocean surface area. Red curve is global-mean sea level observed by satellite altimetry. Both time series have had a linear trend and seasonal cycle removed, and have been smoothed with a 13-month low-pass filter to emphasize low-frequency variations

from the satellite altimetry time series. This simple exercise suggests that the impact of freshwater discharged by rivers on sea level is potentially important, not only at regional scales, but also at global scales.

The second way a river discharge can influence the sea level is through the steric effect, and more precisely the halosteric effect. Commonly, an outflow of riverine water is less dense than the surrounding salty water. This strong density contrast is only partly eroded by mixing and entrainment of ambient coastal ocean water into the buoyant coastal freshwater plume. Thus, a riverine discharge results in a lens of fresher, lighter water that retains its identity while "floating" over the saltier, denser ocean water. Such density anomalies involve sea level signals, baroclinic pressure gradients, and associated currents. As this regional dynamic response is believed to be locally more important than the ocean mass contribution effect (which is more broadly spread over the global ocean) around most of river outlets, it has received considerably more attention in the past decades. It is associated with longer response timescales, and has a regional impact, hence its relevance for coastal sea level variability.

A key question for understanding the associated variability of coastal sea level can be stated as follows: what is the dynamics of the spreading of the fresh anomaly induced by a river plume along the neighboring coastlines, away for the river mouth? "Spreading" here is to be understood generally both in the sense of mixing of the riverine waters with the ambient ocean water, and of transport of the riverine waters away from the river mouth. Strictly speaking, there is also a related thermal effect, due to the fact that a river outflow does not necessarily have the same temperature as the ambient ocean water. However, sea level and density anomalies resulting from this difference of temperature are not considered in this review. This omission is justified based on simple scaling arguments. Assuming a typical haline contraction coefficient of $8 \times 10^{-4} \mathrm{PSU}^{-1}$ and thermal expansion coefficient of $2 \times 10^{-4} \mathrm{degC}^{-1}$, and given a 1 practical salinity unit, 1 PSU (10 PSU) salinity contrast between the river water and ocean water, a corresponding temperature difference of several $\operatorname{degC}$ (several tens of $\operatorname{deg} C$ ) is needed for temperature effects on density to be comparable to salinity effects.

The two above-cited processes, mass contribution and halosteric effect, will be discussed in Sect. 3, in theoretical and realistic frameworks. 


\section{State-of-the-Art Runoff and Freshwater Flux Products}

Direct observational river runoff estimates across the global ocean are largely scattered, incomplete and inhomogeneous, even for the major rivers. This has considerably hampered the scientific progress on our topic. This section aims at improving matters and providing a comprehensive inventory of state-of-the-art databases.

The primary estimation of river flow and discharge is based on in situ observations (Fekete et al. 2000, 2015). In situ gauging networks have been installed for several decades in many river basins, distributed non-uniformly throughout the world, usually managed at local or country level, and primarily motivated by socioeconomic applications (e.g., water resources allocation, navigation and infrastructures, hydroelectric energy, flood hazard). However, the achievement of a comprehensive data collection of continental discharge to the oceans with in situ observations faces many challenges (Trenberth et al. 2007). One of the major obstacles in estimating continental discharge to the ocean is the sparse and incomplete gauging records or unmonitored streamflow. In many regions, especially in the tropics and in high-latitude environments, the collection of data is made difficult by the complexity of the physics of water flow across vast remote and inaccessible regions. For other countries, the cost of data collection can be limited due to economic reasons. As a result, a vast portion of the freshwater discharge to the ocean is ungauged, not adequately measured or has experienced loss of gauges in the past decades (Shiklomanov et al. 2002). Finally, when such collection of data exists, their dissemination is in general restricted, being considered sensitive national information, thus limiting their public access and use for environmental and climate studies (Papa et al. 2012a).

In recent decades, the systematic and global monitoring of rivers became a fundamental objective of the international community, including United Nations organisations, governments, and other public or private institutions. The primary archive for global in situ river discharge data is now the Global Runoff Data Center (GRDC, 2018) that operates under the auspices of the World Meteorological Organisation (WMO).

The GRDC provides a unique collection of river discharge data collected at daily or monthly intervals from more than 8000 stations located in 157 countries, available for non-commercial use upon request (www.bafg.de/GRDC/EN/Home/ homepage_node. html) Table 1 summarizes, as of November 2018, the data available (daily or monthly discharge observations) from GRDC for a selection of 15 of the world's largest rivers at the farthest downstream station before reaching the ocean. As seen in Table 1, while GRDC offers long-term, recent and up-to-date times series (latest observations within the last 5 years for Mississippi, Rio Parana, Ob, Yenisei, Mackenzie), other large river systems show very limited records in time (Mekong, Ganges) and/or not up-todate (Amazon, Congo, Lena, Yangtze, Orinoco, Brahmaputra, Irrawaddy). Some stations offering long-term monitoring (several decades) also suffer from large amounts of missing data on daily or monthly records (Mississippi, Yenisei, Lena, Niger, Yangtze, Brahmaputra).

For specific studies, in order to improve the record length and obtain more recent measurements, users can complement the large database of GRDC by using additional sources providing streamflow data. Those sources can come from in situ or satellitederived observations, and are provided by institutional websites and databases or through personal contacts. Our objectives here are to provide the community with the current and most relevant sources, with a balance between the length of the records, 
Table 1 River discharge data at the farthest downstream stations for 15 of the world's largest ocean-reaching rivers from GRDC (2018): characteristics and availability as of November 2018

\begin{tabular}{|c|c|c|c|c|c|c|c|c|c|c|}
\hline River name & $\begin{array}{l}\text { Station name, } \\
\text { country, GRDC } \\
\text { number }\end{array}$ & Lat (deg) & Lon (deg) & $\begin{array}{l}\text { Catchment size } \\
\left(10^{6} \times \mathrm{km}^{2}\right) \text {; } \\
\text { Distance of the } \\
\text { station to the } \\
\text { river mouths } \\
(\mathrm{km})\end{array}$ & $\begin{array}{l}\text { Period of daily } \\
\text { data avail- } \\
\text { ability }\end{array}$ & $\begin{array}{l}\text { Length of daily } \\
\text { time series in } \\
\text { years ( } \% \text { of } \\
\text { missing data) }\end{array}$ & $\begin{array}{l}\text { Period of } \\
\text { monthly data } \\
\text { availability }\end{array}$ & $\begin{array}{l}\text { Length of } \\
\text { monthly time } \\
\text { in years (\% of } \\
\text { missing data) }\end{array}$ & $\begin{array}{l}\text { Mean annual } \\
\text { stream flow } \\
\left(\mathrm{m}^{3} / \mathrm{s}\right)\end{array}$ & $\begin{array}{l}\text { Mean annual } \\
\text { volume }\left(\mathrm{km}^{3}\right)\end{array}$ \\
\hline Amazon & $\begin{array}{l}\text { Óbidos, } \\
\text { Brazil, } \\
3629001\end{array}$ & $1.92 \mathrm{~S}$ & $55.51 \mathrm{~W}$ & $\begin{array}{l}4.680 \\
700\end{array}$ & 1968-2008 & $41(6.15)$ & 1968-2008 & 41 (n.a) & 178,500 & 5600 \\
\hline Congo & $\begin{array}{l}\text { Brazzaville, } \\
\text { Congo, } \\
1447150\end{array}$ & $4.27 \mathrm{~S}$ & $15.32 \mathrm{E}$ & $3.475 ; 550$ & n.a & n.a & $1971-1983$ & $13(0.0)$ & 41,000 & 1300 \\
\hline Mississippi & $\begin{array}{l}\text { Vicksburg, MS, } \\
\text { USA, } \\
4127800\end{array}$ & $32.32 \mathrm{~N}$ & $90.91 \mathrm{~W}$ & $\begin{array}{l}2.965 \\
350\end{array}$ & 1931-2018 & $88(1.35)$ & $1928-1983$ & $56(63.23)$ & 17,500 & 550 \\
\hline Rio Parana & $\begin{array}{l}\text { Chapeton, } \\
\text { Argentina, } \\
3265600\end{array}$ & $31.57 \mathrm{~S}$ & $60.33 \mathrm{~W}$ & $\begin{array}{l}\text { n.a; } \\
450\end{array}$ & 1975-2014 & $40(0.48)$ & 1975-2014 & $40(0.43)$ & 17,800 & 560 \\
\hline $\mathrm{Ob}$ & $\begin{array}{l}\text { Shalekard, } \\
\text { Russia } \\
2912600\end{array}$ & $66.57 \mathrm{~N}$ & $66.53 \mathrm{E}$ & $\begin{array}{l}2.950 \\
287\end{array}$ & 1954-2010 & $57(1.76)$ & 1930-2015 & $86(12.79)$ & 12,900 & 410 \\
\hline Yenisei & $\begin{array}{l}\text { Igarka, } \\
\text { Russia, } \\
2909150\end{array}$ & $67.48 \mathrm{~N}$ & $86.5 \mathrm{E}$ & $\begin{array}{l}2.440 \\
697\end{array}$ & 1955-2011 & $57(13.05)$ & 1936-2015 & $80(15.0)$ & 19,250 & 610 \\
\hline Lena & $\begin{array}{l}\text { Kusur, Russia, } \\
2903420\end{array}$ & $70.7 \mathrm{~N}$ & $127.65 \mathrm{E}$ & $\begin{array}{l}2.430 \\
211\end{array}$ & 1935-2011 & $77(0.16)$ & 1934-2000 & $67(0.0)$ & 17,100 & 540 \\
\hline Niger & $\begin{array}{l}\text { Lokoja, Nigeria } \\
1834101\end{array}$ & $7.80 \mathrm{~N}$ & $6.77 \mathrm{E}$ & $\begin{array}{l}\text { n.a; } \\
500\end{array}$ & 1970-2006 & 37 (12.03) & 2007-2012 & $6(44.4)$ & 5000 & 160 \\
\hline
\end{tabular}


IS Table 1 (continued)

\begin{tabular}{|c|c|c|c|c|c|c|c|c|c|c|}
\hline River name & $\begin{array}{l}\text { Station name, } \\
\text { country, GRDC } \\
\text { number }\end{array}$ & Lat (deg) & Lon (deg) & $\begin{array}{l}\text { Catchment size } \\
\left(10^{6} \times \mathrm{km}^{2}\right) \text {; } \\
\text { Distance of the } \\
\text { station to the } \\
\text { river mouths } \\
(\mathrm{km})\end{array}$ & $\begin{array}{l}\text { Period of daily } \\
\text { data avail- } \\
\text { ability }\end{array}$ & $\begin{array}{l}\text { Length of daily } \\
\text { time series in } \\
\text { years ( } \% \text { of } \\
\text { missing data) }\end{array}$ & $\begin{array}{l}\text { Period of } \\
\text { monthly data } \\
\text { availability }\end{array}$ & $\begin{array}{l}\text { Length of } \\
\text { monthly time } \\
\text { in years (\% of } \\
\text { missing data) }\end{array}$ & $\begin{array}{l}\text { Mean annual } \\
\text { stream flow } \\
\left(\mathrm{m}^{3} / \mathrm{s}\right)\end{array}$ & $\begin{array}{l}\text { Mean annual } \\
\text { volume }\left(\mathrm{km}^{3}\right)\end{array}$ \\
\hline Yangtze & $\begin{array}{l}\text { Datong, } \\
\text { China, } \\
2181900\end{array}$ & $30.77 \mathrm{~N}$ & $117.62 \mathrm{E}$ & $\begin{array}{l}1.706 \\
510\end{array}$ & 2004-2004 & $1(0.0)$ & $1922-1988$ & $67(25.44)$ & 25,000 & 790 \\
\hline Mackenzie & $\begin{array}{l}\text { Arctic Red } \\
\text { River, } \\
\text { Canada, } \\
4208025\end{array}$ & $67.54 \mathrm{~N}$ & $133.75 \mathrm{~W}$ & $\begin{array}{l}1.660 \\
292\end{array}$ & 1972-2016 & 45 (1.76) & 1972-1996 & $25(0)$ & 9200 & 290 \\
\hline Mekong & $\begin{array}{l}\text { Kompong } \\
\text { Cham, Cam- } \\
\text { bodia, } \\
2569003\end{array}$ & $11.99 \mathrm{~N}$ & $105.47 \mathrm{E}$ & $\begin{array}{l}0.660 \\
420\end{array}$ & 1964-1974 & $11(2.40)$ & n.a & n.a & 13,500 & 425 \\
\hline Orinoco & $\begin{array}{l}\text { Puente } \\
\text { Angostura, } \\
\text { Venezuela, } \\
3206720\end{array}$ & $8.15 \mathrm{~N}$ & $63.60 \mathrm{~W}$ & $\begin{array}{l}0.836 \\
380\end{array}$ & 1923-1989 & $67(1.33)$ & 1923-1989 & $67(1.25)$ & 31,200 & 985 \\
\hline Irrawaddy & $\begin{array}{l}\text { Pyay, Myan- } \\
\text { mar, } \\
2260600\end{array}$ & $18.80 \mathrm{~N}$ & $95.22 \mathrm{E}$ & $\begin{array}{l}0.346 \\
400\end{array}$ & 1996-2010 & $15(0.0)$ & 1996-2010 & $15(0)$ & 11,800 & 372 \\
\hline Ganges & $\begin{array}{l}\text { Hardinge } \\
\text { bridge, Bang- } \\
\text { ladesh, } \\
2646200\end{array}$ & $24.08 \mathrm{~N}$ & $89.03 \mathrm{E}$ & $\begin{array}{l}0.846 \\
250\end{array}$ & 1985-1992 & $8(1.21)$ & 1985-1992 & 8 (1.19) & 10,900 & 345 \\
\hline Brahmaputra & $\begin{array}{c}\text { Bahadurabad, } \\
\text { Bangladesh, } \\
2651100\end{array}$ & $25.18 \mathrm{~N}$ & 89.67E & $\begin{array}{l}0.636 \\
350\end{array}$ & 1985-1992 & $8(0.0)$ & 1969-1992 & $24(44.80)$ & 23,800 & 750 \\
\hline
\end{tabular}




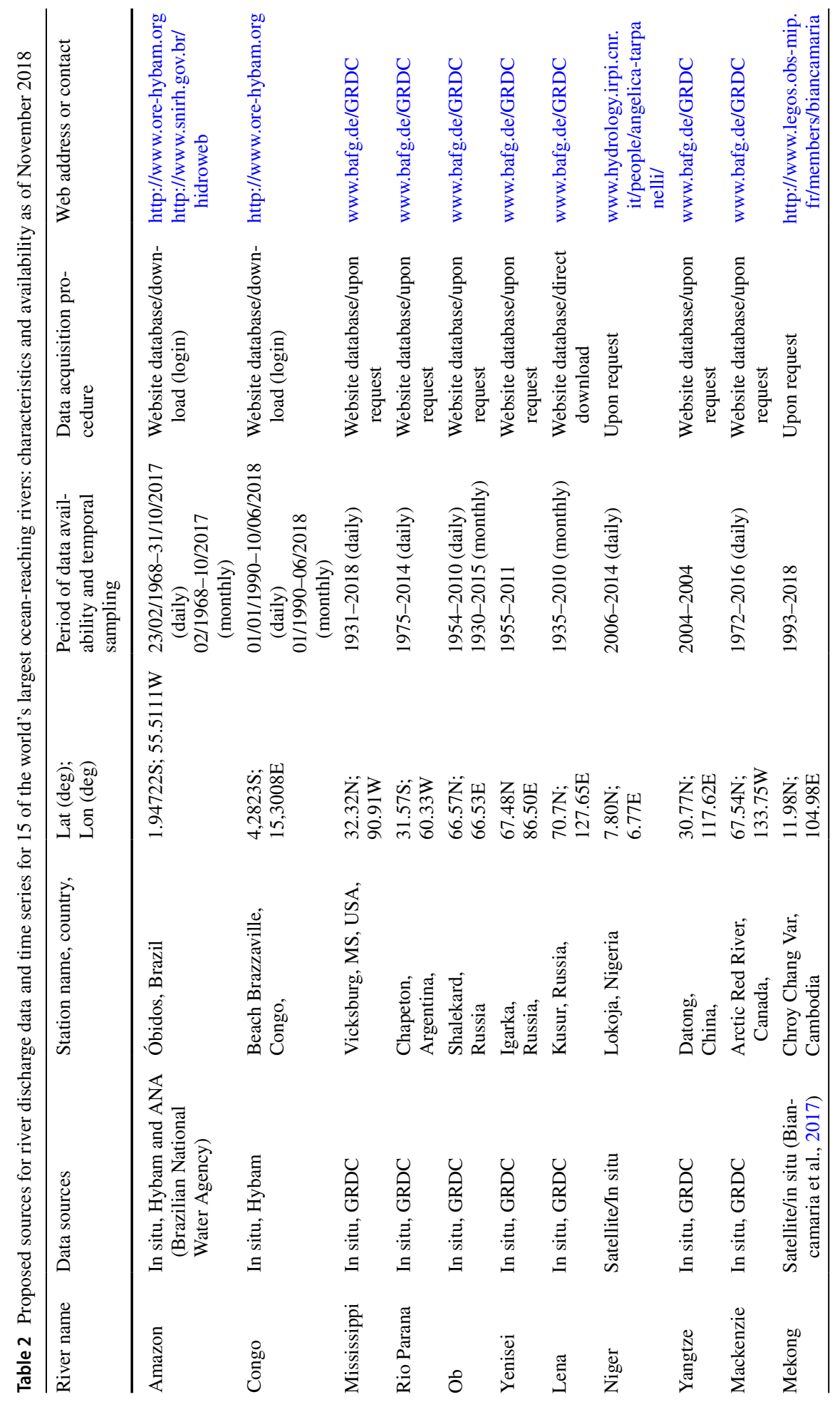




\begin{tabular}{|c|c|c|c|c|c|}
\hline 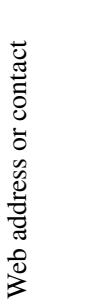 & 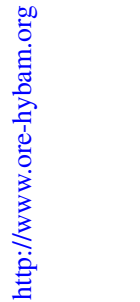 & $\begin{array}{l}0 \\
0 \\
0 \\
0 \\
0 \\
0 \\
00 \\
0 \\
0 \\
0 \\
3 \\
3 \\
3\end{array}$ & 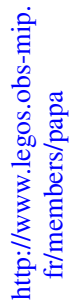 & 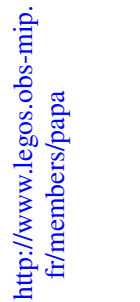 & 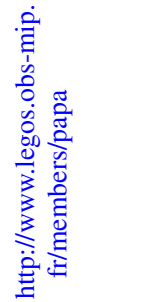 \\
\hline 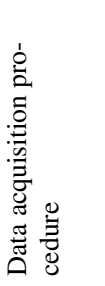 & 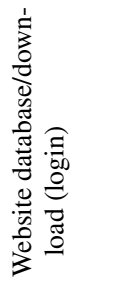 & 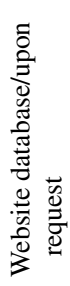 & 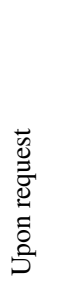 & 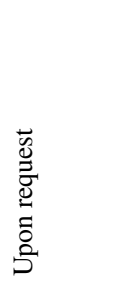 & 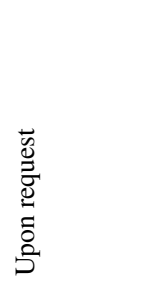 \\
\hline 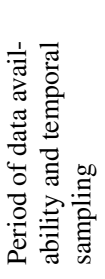 & 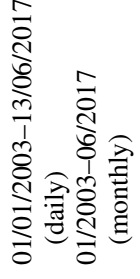 & 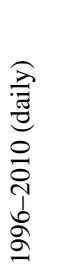 & 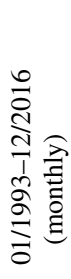 & 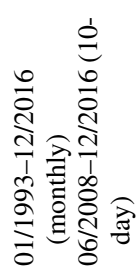 & 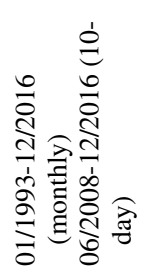 \\
\hline 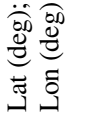 & 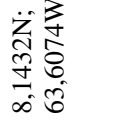 & 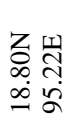 & 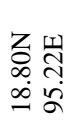 & 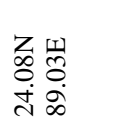 & 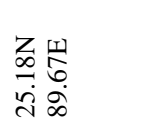 \\
\hline 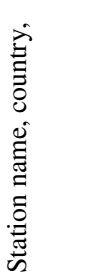 & 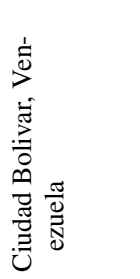 & 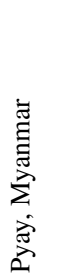 & 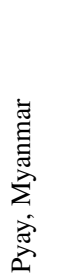 & 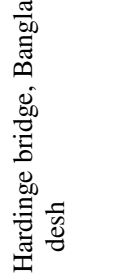 & 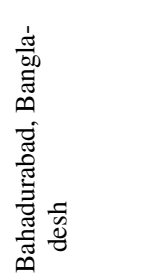 \\
\hline 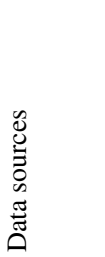 & 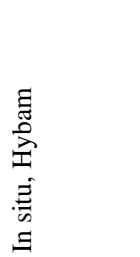 & 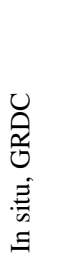 & 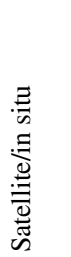 & 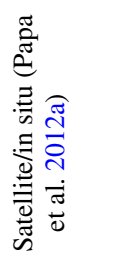 & 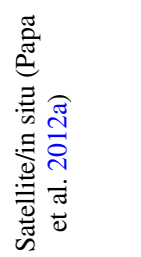 \\
\hline 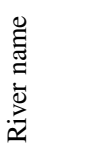 & 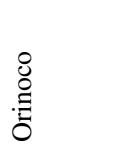 & 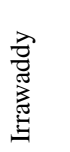 & 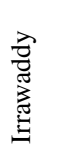 & 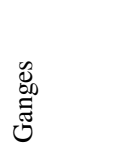 & 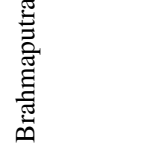 \\
\hline
\end{tabular}


their temporal sampling interval and the availability of up-to-date observations. Table 2 summarizes the proposed collections, their sources, the main characteristics of the time series and how to get access to those data.

For 6 out of the 15 largest rivers we considered, the GRDC database turns out to be the most adequate source for providing river discharge time series. For Mississippi, Mackenzie, Rio Parana, GRDC provides long-term records with recent/up-to-date observations, similar for instance to what is available on the U.S. Geological Survey website (http://nwis. waterdata.usgs.gov/nwis/). For the large Siberian rivers (Ob, Yenisei, Lena), the project R-ArcticNet (A Regional, Electronic, Hydrographic Data Network For the Arctic Region, www.r-arcticnet.sr.unh.edu, Lammers et al. 2001) offers time series similar to GRDC.

For large tropical rivers, alternatives to GRDC limited records range from data archives from international observatories, river basins and water management institutes, to collections that can be obtained only through personal contacts. For the Amazon, Orinoco and Congo rivers, the Observation Service (SO) HyBAm (HYBAM, 2018), "Geodynamical, hydrological and biogeochemical control of erosion/alteration and material transport in the Amazon, Orinoco and Congo basins", provides the research community with long-term and up-to-date time series of river discharge at daily and monthly timescales. As of November 2018, time series of in situ river discharge over the Amazon River (1968-2017 at Óbidos), the Congo River (1990-2018 at Brazzaville) and the Orinoco River (2003-2017 at Ciudad Bolivar) are available on the website http://www.ore-hybam.org. Note that for the Amazon River, the Brazilian National Water Agency (ANA) also provides up-to-date river discharge time series (http://hidroweb.ana.gov.br/)

For the Yangtze River, to our knowledge, no alternative to the short 1-year time series of GRDC is available, despite the fact that longer (since 1950) and more recent (at least 2001-2006) time series from the Changjiang Water Resources Commission exist, as reported in Xu and Milliman (2009).

For large rivers of the Indian subcontinent, public access to long-term and recent river discharge observations is generally restricted. Recent efforts have been undergone to provide to the public such measurements for Indian non-transboundary rivers, including large basins such as Mahanadi, Godavari, Krishna, and Cauvery flowing into the Bay of Bengal. Those data are available on the "Generation of Database and Implementation of Web Enabled Water Resources Information System in the Country" short named as India-WRIS WebGIS (Water Resources Information System of India, www.india-wris.nrsc.gov.in/). However, observations of large Indian transboundary rivers (mainly the Ganges-Brahmaputra-Meghna system and Indus River) are still not freely available. Historically, hydrological observations in the Ganges-Brahmaputra Rivers across Bangladesh have also been carried out by the Bangladesh Water Development Board since the early 1920s (www. bwdb.gov.bd/). However, long-term and recent data records are difficult to obtain in the region and public access is often limited (Jian et al. 2009; Durand et al. 2011) especially for long-term daily Ganges and Brahmaputra discharge time series.

Given the importance of Ganges - Brahmaputra freshwater flux to the Bay of Bengal and its impacts on the regional climate (Neetu et al. 2012; Sengupta et al. 2016), Papa et al. (2012a) developed a methodology using satellite altimetry observations (TOPEXPoseidon, ERS-2, ENVISAT, Jason2/3 missions) to locally estimate river discharge from the systematic monitoring of water levels of these two rivers. Altimetry-derived river water heights are correlated with in situ observed river discharge or height to construct empirical regression curves (called rating curves) so as to provide altimetry-based discharge estimates for times when in situ discharge observations are missing, or even to extend river discharge series forward or backward in time (for more details, refer to Papa et al. (2012a)). 
This technique, despite several limitations (Alsdorf et al. 2007; Papa et al. 2012b), has been shown to be extremely valuable as a complement to ground-based observations where traditional gauge data can be irregular and difficult to obtain. It has been proven advantageous to provide important information for oceanography studies (Akhil et al. 2014; Chaitanya et al. 2015). Over the Ganges and Brahmaputra rivers, altimetry-derived discharge time series are available for each river (Table 2) and as a Ganges-Brahmaputra combined freshwater flux to the Bay of Bengal at the river mouth for 1993-2016 (monthly basis) and for 2008-2016 (10-day basis). Uncertainties are around 10\%, well within the range of errors acceptable for large rivers (a 15-20\% accuracy is generally considered as acceptable (Fekete et al. 2000)). A similar approach has been used for the Irrawaddy River (Frappart et al. 2015), and an altimetry-derived discharge time series for 1993-2016 on a monthly timescale is also available to the community (Table 2) and provides additional valuable information to the traditional gauge data available on the GRDC collection (1996-2010, daily).

For the Mekong River, several institutional sources, such as the Mekong Central Water Commission (MCWC, www.portal.mrcmekong.org) or the Vietnam Southern Regional Hydrometeorological Center (VSRHC, http://www.kttv-nb.org.vn/) also provide in situ water level and discharge information on their data portal. For instance, Tan Chau $\left(10.48^{\circ} \mathrm{N}, 105.13^{\circ} \mathrm{E}\right)$ and Chau Doc $\left(10.42^{\circ} \mathrm{N}, 105.06^{\circ} \mathrm{E}\right)$ stations on the Mekong would offer precious information on continental freshwater flux, but timeseries can be irregular, incomplete, not up-to-date or difficult to obtain. As a complement, and similarly to what is proposed on the Ganges-Brahmaputra or the Irrawaddy rivers, an alternative based on long-term and continuous radar altimetry observations is available and a time series of Mekong river discharge for 1993-2018 can be now accessed for environmental studies (Biancamaria et al. 2017).

Finally, for the Niger River in Africa, very recent satellite-based products inferring river discharge at Lokoja are also available upon request (see Table 2; Tarpanelli et al. 2017, 2018). These estimates are based on a combination on multi-satellite sensors (ModerateResolution Imaging Spectroradiometer MODIS and radar altimetry observations) with a neural network approach, and were found to be a very reliable tool to infer Niger River discharge (2006-2014, daily) with a relative root-mean-square error of $0.12 \%$.

As a complement to in situ archives and satellite-derived river discharge products, efforts have been also made by the community to characterize long-term variations and recent changes of continental discharge to the global ocean using modeling approaches (GRDC 2014; Peel et al. 2006, Fekete et al. 2000). As several methods and results are available, we will not discuss them here in detail. For the oceanographic community, widely used datasets are the ones from Dai and Trenberth (2002) and Dai et al. (2009), where in their latest versions, they combined observations from in situ gauges and simulations from a land surface model to create a dataset of historical monthly streamflow for the world's 925 largest ocean-reaching rivers for 1948-2004. This compilation has been recently updated to include earlier data (going back to the year 1900 in some cases) and more recent records (extending through the year 2010), and is described in Dai (2016). While this dataset represents unprecedented and valuable information on continental discharge into the global ocean, for individual river systems where in situ discharge observations are not available, estimates from Dai et al. (2009) have difficulty in reproducing the interannual variability characterized by large anomalous events. This is the case for instance after 1996 for the Ganges-Brahmaputra, which might have strong impacts on the coastal ocean at various timescales (Durand et al. 2011). Similarly, several recent studies based on observations, models or model-data combinations (Clark et al. 2015; Chandanpurkar et al. 2017; 
Do et al. 2018; Gudmundsson et al. 2018; Suzuki et al. 2018) also provide new global and long-term datasets of continental discharge estimates and freshwater flux to the oceans.

In the near future, the Surface Water and Ocean Topography mission (SWOT, Prigent et al. 2016), now planned for September 2021, is set to measure surface water bodies and to infer river discharge with a repeat cycle of 21 days. Unlike previous altimeters used for hydrological applications (Papa et al. 2012a) that only measure along-track 1-D heights, SWOT will carry a Ka-band radar interferometer across a $120 \mathrm{~km}$ swath capable of deriving 2-D images of surface water height (along with river height, width and slope) with a vertical accuracy of about $1 \mathrm{~cm}$ per $1 \mathrm{~km}^{2}$. The calculation of river discharge will still rely on algorithms that account for the unknown channel depths and flow velocities; however SWOT is expected to provide unprecedented global and continuous discharge measurements from space with spatial and temporal resolutions adequate to oceanographic studies.

\section{Theory, Observation, and Modeling of Continental Freshwater Runoff Impacts on Regional Sea Level}

Here we review current understanding of the influence of continental freshwater runoff from rivers on coastal sea level, including the roles of mass and steric changes, considering theoretical and idealized frameworks as well as more realistic data and model settings.

\subsection{Qualitative Relationships Between Tide Gauge Records and River Runoff}

Previous studies consider the influence of forcing by river runoff on sea level from tide gauge data. Many of these studies are qualitative, based on intuitive reasoning or statistical methods, such as correlation or regression analysis. While it is difficult to generalize, these studies find that river runoff can have more or less influence on coastal sea level, depending on space and timescales, region and time period. Here we summarize the main findings from some example studies, with an emphasis on the relevant timescales, time periods, and geographic regions.

Roden (1960) observes that between 15 and $50 \%$ of the anomalous sea level variation at Astoria, Oregon (US West Coast) is due to anomalous Columbia River discharge, depending on timescale (cf. Chelton and Davis 1982; Chelton and Enfield 1986). Meade and Emery (1971) argue that river runoff accounts for between 20 and $31 \%$ of detrended interannual sea level variance during 1930-1970 along the US East and Gulf Coasts. Royer (1979) discusses the influence of runoff on annual changes in coastal steric sea level along the Gulf of Alaska. Blaha (1984) shows that freshwater runoff from the Savannah River and Chesapeake Bay does not explain variance in nonseasonal monthly tide gauge sea level records at Fernandina, Charleston, and Norfolk (US Southeast Coast) during 1955-1975. In a study of tide gauges on the east coast of South America, Aubrey et al. (1988) note large monthly sea level variations in tide gauge data from locations near or within major rivers-such as Isla Martin Garcia (Argentina), Colonia (Uruguay), and Montevideo (Uruguay)—situated in the Río de la Plata. Tsimplis and Woodworth (1994) study the sea level seasonal cycle from globally distributed tide gauges and interpret large amplitudes observed in tide gauge data along the Ganges and Irrawaddy Deltas, Mahi River, Yellow River, St. Lawrence River, and Río Uruguay as the consequence of river outflows. Based on correlation analyses, Gough and Robinson (2000) suggest that discharge from the Churchill River explains $43 \%$ of the monthly sea 
level variance in the Churchill tide gauge records in Hudson Bay (Canada) from 1974 to 1994. Hong et al. (2000) describe their effort to find a statistically significant relationship between observed decadal variability in US East Coast sea level and river runoff as "fruitless". Judging from simulations with a reduced-gravity ocean model, Han and Webster (2002) find that the influence of river discharge on interannual sea level variability in the Bay of Bengal is negligible. Using monthly river runoff data along with sea level from tide gauges and satellite altimetry, Han (2002) reasons that runoff from the St. Lawrence River (Canada) did not cause an interannual decline in sea level on the eastern Scotian Shelf during 1997-1999.

Based on study of tide gauge data and a barotropic model, Proshutinsky et al. (2004) find that seasonal increases in Arctic sea level at locations near river mouths during June and July result from increased river discharge associated with melting snow, but note that long-term (1948-2002) coastal sea level trends in the Arctic due to river runoff are small and negligible. Vinogradov and Ponte (2011) suggest that strong river runoff could be responsible for discrepancies observed between interannual sea level changes from tide gauge records and satellite altimeter data around the Ganges River delta from 1993 to 2008; similar suggestions are made more recently by Ruiz Etcheverry et al. (2015) for the annual cycle in that region. Torres and Tsimplis (2012) suggest that outflow from the Magdalena and Atrato Rivers contributes to the sea level seasonal cycle in the southeastern Colombian Basin (Caribbean Sea). Studying the seasonal cycle in coastal sea level from monthly tide gauge data in the Gulf of Cadiz (Portugal and Spain), Laiz et al. (2013) argue that runoff from the Guadalquivir River explains $18 \%$ of the barometrically corrected sea level variance at nearby Bonanza, mostly due to strong discharge events in winter and autumn, but they find that runoff from the Tinto-Odiel River System has no impact on sea level as observed at the close-by Huelva tide gauge. Saramul and Ezer (2014) determine that river discharge has only a small impact on seasonal changes in sea level in the Gulf of Thailand. Becker et al. (2014) explain that tide gauge data in the St. Lawrence River and Gulf of St. Lawrence are affected by strong discharge from upstream runoff. Svendsen et al. (2016) note that, given their location in the Gulf of $\mathrm{Ob}$, sea level observations from the Antipayuta tide gauge (Russian Arctic) are largely indicative of river runoff. Calafat et al. (2018) compare the sea level annual cycle from tide gauges on the US Southeast Coast to river discharge from major rivers flowing into the Atlantic Ocean and do not find good agreement. Piecuch et al. (2018) corroborate earlier findings from Meade and Emery (1971) using updated datasets over longer and more recent time periods along the US East and Gulf Coasts.

Together, these studies reveal that river runoff can be an important driver of coastal sea level variation on monthly and longer timescales, but seldom is it the dominant forcing mechanism. Moreover, these works clarify that something like a "first law of geography" does not hold for the relationship between variable river runoff and coastal sea level-it is not necessarily true that sea level at some location geographically closer to a river mouth is more strongly affected by river discharge than in another location farther away. For example, the fact that Laiz et al. (2013) find no relation between discharge from the Tinto-Odiel River System and sea level at nearby Huelva could in part be because that tide gauge is situated slightly southeast of the river mouth, whereas - under the influence of Earth's rotation-seasonal river discharge would have the tendency to "turn away" and flow northwest along the coast in the sense of a coastal Kelvin wave (Piecuch et al. 2018). This underscores the need to better understand physical processes mediating relationships between river runoff and sea level at the coast. 


\subsection{Ocean mass Contribution of Runoff}

One way of investigating the ocean mass contribution of river outflows is through "hosing experiments" performed with ocean numerical models. These experiments simulate the sea level response to local inputs of water mass into the ocean. As such, they can help understand what would result from anomalous runoff in river outlets or coastal ice bodies. Based on idealized ice-melting experiments, Lorbacher et al. (2012) observed that the sea level response to mass input is mediated by barotropic waves, which propagate very quickly across the global ocean. They also determined that the global ocean gets roughly uniformly adjusted within a few days. As emphasized by Stammer (2010), this implies that the sea level response to the ocean mass contribution of localized runoff is essentially global, not regional, whatever the location of the source point. However, further studies are needed based on idealized experiments or theoretical analyses, in particular focusing on specific geometries such as shallow shelves and narrow semi-enclosed basins (e.g., Ponte 2006; Dobslaw and Thomas 2007).

As an example of rivers discharging to the open ocean, the ocean mass contribution of runoff was assessed by Laiz et al. (2014) for the case of the Gironde (west coast of France, northeastern Atlantic). In their regional circulation model, even when focusing only on flood periods, the ocean mass contribution of the sea level response to discharge is subcentimetric, including in the immediate vicinity of the river mouth. This modest signature may be related to the weak discharge of the river considered $\left(1100 \mathrm{~m}^{3} / \mathrm{s}\right.$ mean outflow). Still, one cannot exclude significant regional impact on coastal sea level driven by more powerful rivers, in particular those outflowing in marginal seas. For instance, Fig. 4 presents the amplitude of the annual cycle of sea level simulated in a barotropic model of the Bay of Bengal. The combined discharge of the rivers outflowing in the Northern Bay of Bengal (Ganges-Brahmaputra-Meghna and Hooghly rivers) is large (see Sect. 2), with

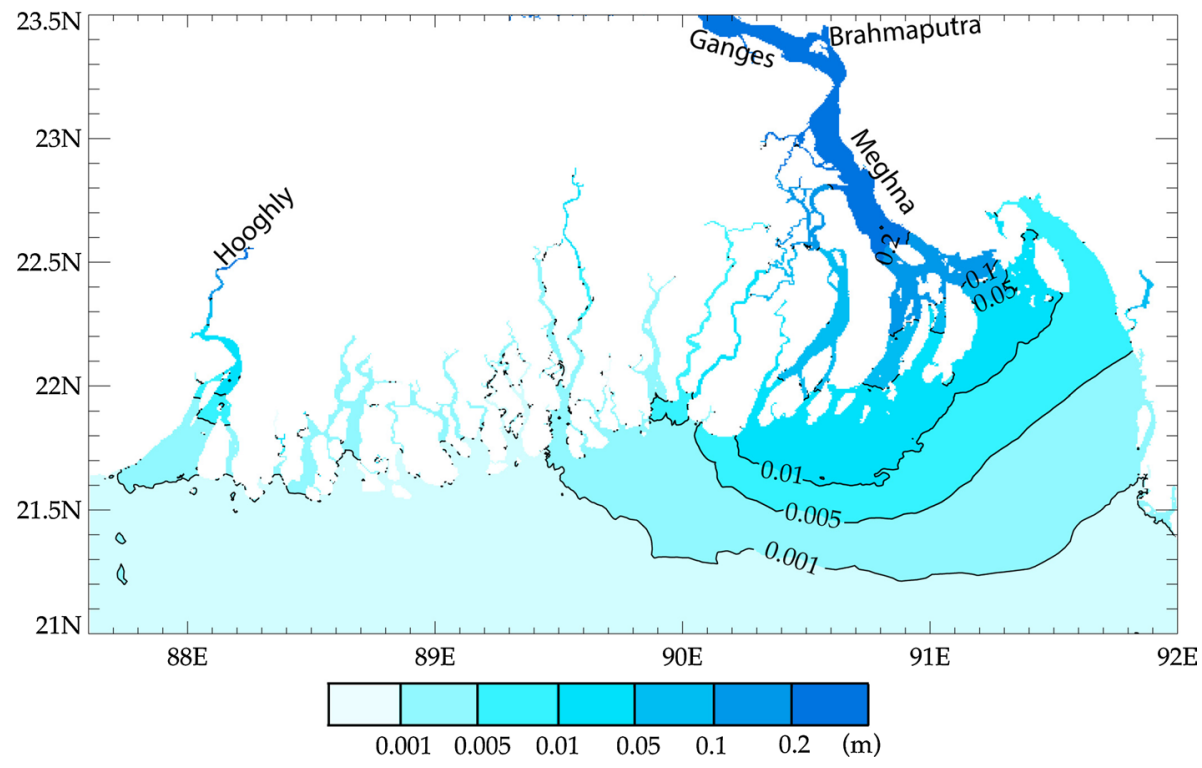

Fig. 4 Amplitude of the annual harmonic of sea level in a barotropic model of the Bay of Bengal forced by seasonally varying rivers discharges 
summer season discharge roughly equivalent to the Amazon yearly average discharge. The model setup is similar to Krien et al. (2016). The tidal forcing comprises only high-frequency constituents (diurnal, semi diurnal, semi-monthly and monthly periods), and the model is forced by time-varying discharge at its upstream boundaries. Hence, any lowfrequency (seasonal-to-annual) variability of the simulated water level can only result from the mass contribution of these rivers. Figure 4 can thus be seen as a measure of the ocean mass contribution of these rivers to the regional annual sea level variability. The amplitude of the annual sea surface height variability decays sharply when moving away from the mouth of Meghna along the coasts of the Bengal delta, from values of about $20 \mathrm{~cm}$ right at the mouth, to about $1 \mathrm{~cm}$ some $70 \mathrm{~km}$ away. Beyond $150 \mathrm{~km}$ from the outlet, the amplitude is less than $1 \mathrm{~mm}$.

In the same vein, Dobslaw and Thomas (2007) as well as Peralta-Ferriz and Morison (2010) investigated the seasonal changes in Arctic Ocean bottom pressure (primarily equivalent to ocean mass, and thus contributing to sea surface height). They suggested that the observed changes, reaching $2 \mathrm{~cm}$ in amplitude, can be reasonably well explained by a partial trapping of the discharged water within the Arctic basin. This trapping appears to result from a barotropic geostrophic circulation (involving the whole water column) around the Arctic Ocean, accompanied by an outflow to the adjacent ocean basins through narrow frictional straits. A similar dynamics may be expected in other semi-enclosed basins subject to intense runoff, such as the Baltic Sea or the Black Sea. Volkov et al. (2016) considered the specific case of the Black Sea, a marginal basin connected to the Mediterranean Sea through a series of narrow and shallow choke points. They suggested the possibility of significant mass accumulation driven by freshwater input, at seasonal and longer timescales. Given that more than half of the freshwater received by the Black Sea comes from rivers (Danube, Dnepr and Don in particular), their study calls for a careful examination of the specific role of hydrologic variability of this large drainage basin, among others, on the seasonal-to-decadal sea level variability.

In summary, the contribution of mass effects to coastal sea level anomalies associated with runoff is expected to be relatively weak in most cases because of the rapid isostatic adjustment through barotropic dynamics. However, stronger dynamic mass effects are possible, for example, in the case of discharge into a semi-enclosed marginal sea connected to the global ocean through a narrow strait, where frictional processes can locally trap the mass input on certain timescales (e.g., Peralta-Ferriz and Morison 2010; Volkov et al. 2016). Careful evaluation on a case by case basis is warranted, apart from consideration of mass effects on estuarine sea level, which will likely be important in most cases.

\subsection{Halosteric Height Contribution of Runoff}

The spreading of river waters in the ocean, which governs the spatiotemporal structure of runoff-induced steric height anomalies for any river outlet, is driven by mixing (mostly vertical) and transport (mostly horizontal) of the freshwater in the surrounding ocean. The review by Horner-Devine et al. (2015) distinguishes three adjacent domains in a river plume: the near-field, close to the source, where the plume is marked, thick (typically occupying the whole water column), hence where the halosteric sea level effect is expected to be strong; the mid-field, located further offshore, where rotation effects are prominent; and the far-field, where the memory of the initial momentum of the discharge is lost, but where the water mass still shows distinct characteristics (in particular lower salinity) compared to ambient waters. The latter domain can extend hundreds of kilometers or more from the 
river mouth in some cases, as we shall see in the next section. Garvine (2001) and Wu et al. (2014) identified three dominant types of river plumes. The first type turns right (in the northern hemisphere) upon entering the ocean, and hugs the coast in the direction of propagation of coastally trapped waves. This pattern is commonly observed in numerical simulations with idealized geometry (e.g., McCreary et al. 1997), where the size of the outlet is large compared to the Rossby radius of deformation (typically in broad deltas). The second type also includes spreading to the left of the river mouth, in the northern hemisphere, under some special conditions for discharge rates, flow structure, bathymetry and mixing at the mouth (e.g., Garvine 1999, 2001; Yankovsky 2000); it is commonly seen in idealized numerical experiments but rarely found in nature. The third type of plume turns right (in the northern hemisphere) but gets trapped in an anticylonic bulge, that never reaches a steady state despite export by a geostrophic coastal current (Pichevin and Nof 1997; Nof and Pichevin 2001; Garvine 2001; Fong and Geyer, 2002; Nof 2005). A growing sea level anomaly can occur in the absence of background circulation, significant mixing or external forcing.

Simpson (1997) and Horner-Devine et al. (2015) reviewed the various processes that can alter the idealized picture of plume spreading presented in the previous paragraph. Four different kinds of processes govern the spreading of a freshwater plume: (1.) transport by the low-frequency, large-scale to mesoscale coastal circulation (typically geostrophic flow, including the buoyancy-driven anticyclonic flow generated along the outer edge of a river plume); (2.) transport by the wind-driven ageostrophic circulation (typically Ekman drift); (3.) mixing (on the horizontal and on the vertical) of the plume waters with surrounding ocean waters; and (4.) transport by the tidal flow. We hereafter illustrate each of these processes through a few representative, realistic cases reported in the literature.

\subsubsection{Transport of River Discharge by Large-Scale to Mesoscale Coastal Circulation}

Probably on account of the nature of western boundary currents as swift and turbulent, the influence of regional circulation on river plumes transport has been mostly studied in western boundary regimes. Muller-Karger et al. (1988) suggested that the Amazon plume propagates northwestward, hugging the northern coast of South America, only during the winter-spring season, whereas it is carried offshore by the seasonal North Brazil Countercurrent, all the way to Africa, during summer-fall. Similarly, Guo and Valle-Levinson (2007) evidenced the role of the boundary current of the northwestern Atlantic in the export pathway of the Chesapeake Bay plume. The southward-flowing coastal current appears responsible for the southward export of the fresh plume. Along the same shoreline, but considered at a larger scale (all along the US East Coast), Piecuch et al. (2018) investigated the variability of the buoyancy-driven along-shore flow (and its associated change in coastal sea level) induced by the interannual to interdecadal variability of continental discharge. They concluded that river discharge and the associated alongshore flow make a significant contribution to variability in coastal sea level. In the tropics, Benshila et al. (2014) modeled the transport of Ganges-Brahmaputra freshwater along the western boundary of the Bay of Bengal, resulting in a so-called "river in the sea" (Chaitanya et al. 2014) that extends more than $2000 \mathrm{~km}$ from the river mouth when the southward-flowing western boundary current is fully developed. This basin, like several others, is subject to intense monsoonal winds, which induce an annual reversal of the boundary currents. This study illustrated that the seasonal export of riverine freshwater far from the source results both from the basin-scale boundary 


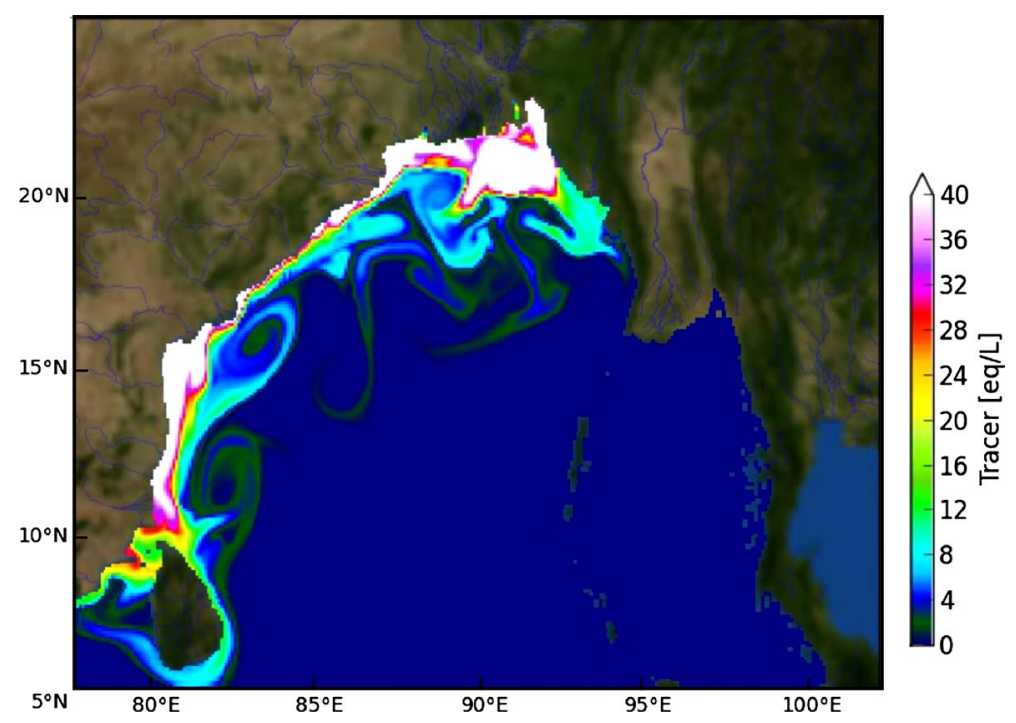

Fig. 5 Passive tracer concentration in a numerical model simulation of the Ganges-Brahmaputra outflow in a regional circulation model of the Bay of Bengal on 22/11/2003. The colour scale (in arbitrary units) represents the concentration of the water of riverine origin. After Benshila et al. (2014)

current, that conveys the plume up to the southern limit of the Bay of Bengal, and from mesoscale instabilities of the boundary current, inducing recirculation and offshore export of the fresh plume (Fig. 5). It was found that a similar transport by the basinscale coastal circulation is largely reponsible for the export of Ganges-Brahmaputra plume waters at interannual timescales (Durand et al. 2011; Chaitanya et al. 2015). In the western tropical Atlantic, Coles et al. (2013) and Fournier et al. (2017a) similarly put forward the role of mesoscale eddies in the transient offshore export of the Amazon plume waters.

In the specific case of monsoonal outflows, caution is needed when trying to interpret the observed freshwater plumes pathways and the associated impact on coastal sea level. Indeed, the monsoonal variability of the atmosphere does not only induce vigorous seasonal changes of precipitation and discharge, but also-and primarily-seasonally reversing winds. Over the tropical oceans, such reversing winds have the potential to trigger marked changes in the vertical density profile in the water column, through baroclinic adjustments. These baroclinic perturbations are associated with significant thermosteric sea level changes (e.g., Shankar et al. 2002, 2010) that can interfere constructively or destructively with the halosteric anomalies associated with the river plumes, depending on the relative timing of the monsoonal winds compared to the seasonal timing of precipitation and runoff. For the specific case of the coastline of the Bay of Bengal for instance, the relative timings of the two factors are such that the winddriven thermosteric sea level variability is largely in phase with the riverine halosteric contribution, with comparable contributions of the two processes near the mouth of Ganges-Brahmaputra during the summer monsoon sea level rise (April-June) (Fig. 6). Similar interfering effects may exist in the other monsoonal outflows, with phasing of thermosteric and halosteric sea level changes being probably highly site-dependent. 


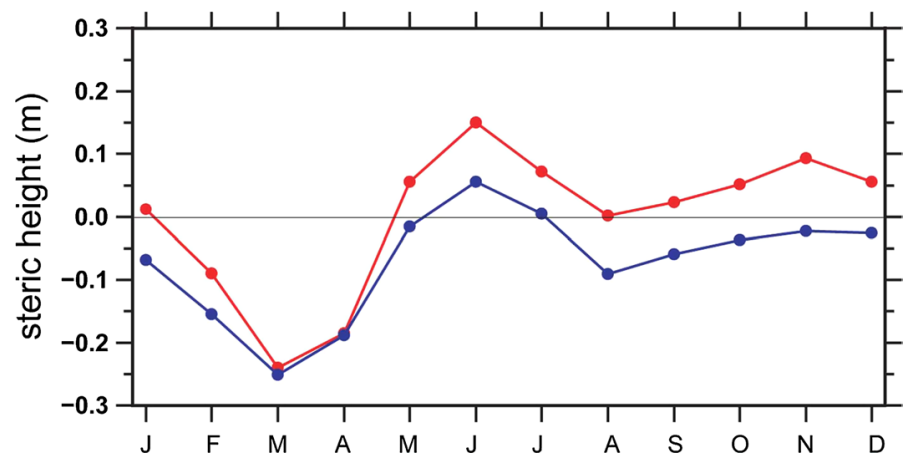

Fig. 6 Seasonal cycle of steric height anomaly observed off the mouths of Ganges-Brahmaputra in the northern Bay of Bengal $\left(88.53^{\circ} \mathrm{E}, 20.5^{\circ} \mathrm{N}\right)$, from the in situ dataset of Sherin et al. (2018). The red curve represents the total steric height, whereas the blue curve represents the thermosteric component only (computed by assuming a constant salinity, hereby canceling the halosteric height anomaly)

\subsubsection{Transport of River Discharge by Local Wind-Driven Circulation}

The strong stratification existing at the base of a surface-advected plume tends to prevent the downward transfer of momentum injected by the wind, favouring swift surface-trapped Ekman drift, that in turn can significantly influence the plume pathway and its imprint on coastal sea level. Fong et al. (1997) observed very contrasted patterns of the coastal plume of the Gulf of Maine (northwestern Atlantic), under contrasted wind regimes. The offshore plume extent was typically 4 times larger during upwelling-favorable wind events, compared to downwelling-favorable periods. They concluded that this was explained by reversing cross-shore currents, well consistent with Ekman drift. Similarly, Sree Lekha et al. (2018) analyzed the offshore export of Ganges-Brahmaputra freshwater in the northern Bay of Bengal. They concluded that the overall export is largely driven by Ekman drift, under the favorable conditions of along-shore winds. The thin freshwater lens overlays a sharp pycnocline that concentrates wind-driven momentum in this shallow layer. It results in a swift offshore Ekman flow that drains the coastal plume away from the shore, with salinity advective rates-of-change several times larger than whatever has been reported in oceanic regimes located far from any river outflow.

\subsubsection{Mixing and Small-Scale Processes Influencing Discharged Waters}

The extreme magnitude of the seawater density gradients associated with river plumes at fine scale, both on the horizontal at their outer edge, as well as on the vertical at their bottom, puts stringent constraints on the skill of the numerical models used to simulate their spatiotemporal evolution and the associated impact on coastal sea level. However, an appropriate modeling of the density gradients is an obvious pre-requisite in any numerical study targeting a proper representation of the coastal sea level in plume regimes. Beyond the issue of model grid resolution, the sub-grid-scale parameterizations are instrumental for the realism of state-of-the-art models in such regimes. Vertical mixing in particular appears as a key ingredient of the evolution of plumes simulated by the numerical models. $\mathrm{Li}$ et al. (2005) analyzed the sensitivity of the fresh plume of Chesapeake Bay to various 
mixing schemes in a high-resolution regional model. They came to the conclusion that none of the vertical mixing schemes they tested allows to curb the excess vertical diffusion seen in their model through the bottom of the river plume; however the turbulent closure schemes they tested are commonly used among the community, even today.

In line with these results, Kärnä et al. (2015) investigated the sensitivity of freshwater plume characteristics to their model numerical setup for Columbia River, by varying the spatial grid size and time step. They restricted their analysis to super-fine grids, with resolution better than $100 \mathrm{~m}$, which stands at the forefront of the modeling setups currently used in regional simulations of large river deltas and large estuaries outflows. In the plume region, in the near-shore domain, they evidenced a high sensitivity of the model skill to the size of both the spatial grid and the time step, even within this context of well-resolved grids. This suggests that a major issue for the near future regards the computational cost of the numerical models targeting a proper representation of river plumes and associated coastal sea level variability at regional scales. These authors all agree that model skill is more limited in conditions of peak flood plumes than in conditions of moderate discharge.

\subsubsection{Effect of the Tides on River Discharge}

For coastal plumes being restricted to shallow regions, the tidal flow naturally appears as a possible prominent driver of the freshwater plume pathways and associated imprints on the regional sea level. Essentially two aspects of the tidal influence can be identified in the plume regions. The first one is the direct transport of the freshwater by the tidal flow, which can consist of the advection by tidal residual current (i.e., nonzero long-term mean of the tidal flow) or Stokes drift (i.e., nonlinear interaction between tidal elevation and tidal flow, resulting in a net transport of freshwater in the direction of tide propagation). Wu et al. (2014) quantified these contributions for the Yangtze plume outflow in the East China Sea. They concluded that the Stokes drift is largely responsible for the northward along-shore propagation of the plume upon entering the ocean. For this particular case of the Yangtze plume, Wu et al. (2011) evidenced that the overall contribution of the various tidal effects dominate the freshwater dispersal in the neighborhood of the mouth, including under windy conditions, while the wind forcing and the transport by shelf currents become prominent further away (typically off the shelf edge).

The second way for the tide to impact river plume pathways and coastal halosteric sea level anomalies is by indirectly modifying the background (non-tidal) coastal flow. A river plume is inherently associated with a very strong density stratification at its base, driven by the vertical salinity gradient. This stratification has the potential to modulate the shear instability, and thus the production of turbulence, in the frictional bottom boundary layer (e.g., Simpson 1997). When the tidal flow is strong enough (typically in macrotidal regimes and/or during spring tides), the flow can become unstable and the horizontal momentum becomes vertically mixed. In such a case, the salinity also becomes vertically mixed, resulting in a so-called bottom-advected plume, as opposed to a surfaceadvected plume (Guo and Valle-Levinson 2007). The enhanced vertical mixing generally leads to reduced surface velocity, hereby impacting the offshore export of the plume waters far from the river mouth, which in turn influences the coastal sea level anomaly. This mechanism was identified as responsible for the contrasting pattern of the freshwater front at the mouth of the Amazon during spring and neap tides (Geyer 1995; Geyer and Kineke 1995). Guo and Valle-Levinson (2007) also observed that the same process of tidally driven vertical mixing was needed to ensure a proper simulation of the Chesapeake 
Bay plume in their model. Similarly, Palma and Matano (2012) concluded that this process largely shapes up the Magellan plume along the southeastern coast of South America. Hordoir et al. (2006) reviewed possible strategies to parameterize the tidal mixing in order to realistically simulate the fate of river plumes in coarse and/or non-tide-resolving ocean general circulation models.

\section{Observational Challenges}

At this stage, it is clear that most of our background knowledge is based on numerical modeling studies. This can be explained by the fact that many observing systems are designed for the deep ocean, and turn out to be of limited use for the monitoring of coastal sea level in plume regions. Here we review these limitations, for both in situ and satellite observational techniques.

\subsection{Spaceborne Altimetry}

Originally conceived for accurate monitoring of the sea surface height in the offshore ocean, spaceborne altimetry performs relatively poorly in the near-shore regions due to errors in the altimetric observations themselves as well as uncertainties in the corrections that need to be applied (Cippolini et al. 2010; Vignudelli et al. 2011; Vignudelli et al., this issue). In order to obtain acceptable error budget of altimetry products in the coastal domain, one has to operate dedicated re-processing of existing datasets (e.g., Passaro et al. 2015; Gómeze-Enri et al. 2016; Birol et al. 2017). Still, the resulting errors are typically in the range of several dozens of centimeters in coastal plumes. River runoff and associated signals (sea level, alongshore currents, etc.) can be strongly trapped to the coast (HornerDevine et al. 2015). The offshore scale of the trapping is on the order of the baroclinic Rossby radius, which can be expressed as a nonlinear function of river outflow (e.g., Piecuch et al. 2018). For a river with strong outflow at mid-latitudes (e.g., Mississippi River), the Rossby radius is $<10 \mathrm{~km}$. This offshore length scale is important, because the quality of data from satellite altimetry, even today, is degraded within $\sim 10-20 \mathrm{~km}$ of the coast.

These simple scalings suggest that satellite altimeters might not register coastal sea level signals driven by river runoff (Vinogradov and Ponte 2011). However, the above considerations are somewhat idealized and omit other relevant complicating factors, such as sloping bathymetry, alongshore winds, and mean flows. For example, discharge from the Mississippi River hit a 63-year high during the summer of 1993; this exceptional runoff was driven far offshore on the shallow shelf due to persistent westerly and southwesterly winds during July and August of that year and interactions with the Loop Current (e.g., Walker et al. 1994). As the performance of coastal altimetry is gradually improving (Vignudelli et al., this issue), it will be timely to re-visit the signature of river plumes (in particular the largest ones) on near-shore sea level based on the latest re-processed altimetric datasets. The limitations of the classical radar altimetry missions also put considerable expectation in the upcoming synthetic aperture radar (SAR) missions, and in particular in the swath SAR altimetry such as foreseen from the SWOT mission (NASA/CNES), which will yield effective sea level measurements within a few hundreds of meters off the shoreline (Dufau et al. 2016; Biancamaria et al. 2016). 


\subsection{Spaceborne Salinity}

The last decade has seen a series of satellite missions dedicated to the observation of sea surface salinity, based on microwave radiometry. The first two missions, Soil Moisture Ocean Salinity (SMOS by ESA) and Aquarius (NASA and the Space Agency of Argentina) were initially found not to perform well in coastal regions, including in plume regions (e.g., Reul et al. 2014; Akhil et al. 2016). Basically these early missions were not usable in the first $100 \mathrm{~km}$ coastal belt. Lately, the situation has significantly improved, through dedicated re-processing of early datasets (e.g., Boutin et al. 2018). The latest Soil Moisture Active Passive (SMAP) satellite mission (NASA) also allowed the scientific community to move forward in the monitoring of coastal salinity, with measurements typically usable as close as $40 \mathrm{~km}$ from the shore in large plume regimes (Fournier et al. 2017a, b; da Silva and Castelao 2018). However, one has to keep in mind that these spaceborne radiometers provide estimates of surface salinity only, which can not be directly related to halosteric sea level anomalies as the vertical extent of the plumes is not observed.

\subsection{Tide Gauges}

Tide gauges are the main tool for monitoring the coastal sea level changes since the mid19th century. Compared to satellite altimeters, tide gauges have a relative advantage in terms of observing the impact of river runoff on sea level. Located along the coast within harbors or inside estuaries, tide gauges can in principle detect the narrow coastally trapped sea level signals typically associated with river runoff, which are not always faithfully captured by satellite altimetry. However, tide gauges are not without their own issues, and there are particular difficulties associated with the analysis of these data. Tide gauge records represent measurements made at a point in space. Given a single tide gauge time series, all wavenumbers are aliased, and it is impossible to infer the spatial scales associated with the sea level signals being observed.

Another challenge relates to the nature of the measurement itself; since tide gauges are affixed to land, the measure is relative in nature, as it reflects not only changes in sea surface height, but also any motions of the Earth's crust. Such vertical land motion can be due to glacial isostatic adjustment, tectonic activity (Ballu et al. 2011), groundwater withdrawal (Emery and Aubrey 1991), sediment loading (Karpytchev et al. 2018), among other effects. These effects can be substantial in large estuaries and deltas, as well as in regions uplifting or subsiding in ongoing response to the last deglaciation. For example, during the last half century, sea level has risen much faster than the global mean due to groundwater extraction in Bangkok (Thailand) (Emery and Aubrey 1991; Phien-wej et al. 2006) and in Manila (Philippines) (Rodolfo and Siringan 2006), whereas sea level has been falling for centuries in Stockholm (Sweden) due to postglacial rebound in response to the melting of the former Fennoscandian Ice Sheet (Ekman 1996). For this reason, it is important to have data of vertical land motion (e.g., from continuous Global Positioning System devices) colocated with or nearby to tide gauges to distinguish sea surface height from vertical crustal motion (e.g., Santamaria-Gomez et al. 2017; Marcos et al. 2019).

\subsection{In Situ Moorings, Ship-Borne Surveys}

The estuarine and riverine neighborhoods are shallow, and in general subject to swift tidal currents, where fishing and navigation activities can be intense. As a result, many in situ 
surveys conducted in the past consisted of dedicated ship-borne cruises, operated on large vessels. One example is the AMASSEDS (A Multidisciplinary Amazon Shelf SEDiment Study) project (Nittrouer et al. 1991) dedicated to the observation of the Amazon outflow. This ambitious program turned out to be very successful in regards to the general understanding of the physics of the Amazon fresh plume (e.g., Geyer 1995; Lentz and Limeburner 1995), but the constraints of in situ operations in such environments prevent tackling timescales longer than about one season in the surveys. This limits the scientific scope of the subsequent process studies, precluding in particular the assessment of the longer timescales. Long-term deployments of in situ moorings, for instance, are often not tractable in strong river plumes. The deltas and estuaries being obviously located in exclusive economic zones, territorial issues also arise when it comes to designing long-term international in situ observing networks. This has led, in several cases, to confinement of in situ surveys of river plumes to international waters (beyond the 200 nautical miles limit), which precludes a detailed investigation of the plume dynamics at its source, and of its imprint on coastal sea level. One such example (among others) is the recent OMM-ASIRI (Ocean Mixing and Monsoons-Air-Sea Interactions in the Northern Indian Ocean) international program (Wijesekera et al. 2016), that could survey the narrow band of international waters of the central Bay of Bengal.

\subsection{Toward the Future}

Gliders and profiling floats, which require typically at least $50 \mathrm{~m}$ depth of water to operate safely, do not currently appear as relevant means of observing the near-shore plumes. However, lightweight surface vehicles, either towed or autonomous, fitted with GNSS receivers, offer promising performances (Marcos et al. 2019) and can already be used in plume regions. Figure 7 displays an example of a towed GNSS blanket experiment carried out across the plume of Ganges-Brahmaputra along the coast of Bangladesh, during the postmonsoon season of 2015. At this time of the monsoonal cycle, the cumulated discharge of Ganges-Brahmaputra to the Northern Bay of Bengal reached $900 \mathrm{~km}^{3}$. Figure 7 shows that such a device can monitor the sea surface slope associated with the plume front, separating
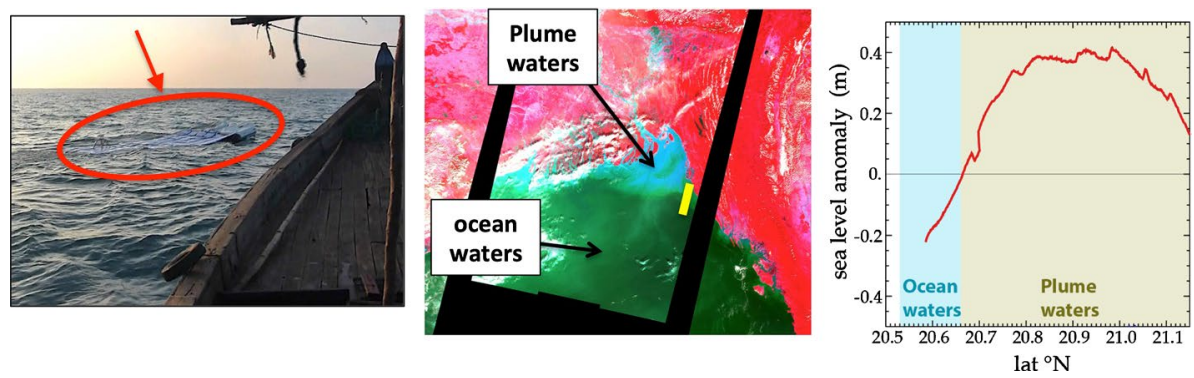

Fig. 7 Towed GNSS blanket experiment carried out in the Ganges-Brahmaputra plume region in November 2014. (left) Experimental setup with the GNSS blanket highlighted in red. (centre) Trajectory of the ship (in yellow), across the front separating the plume waters (blueish) from the ocean waters (green); the background is the quasi-true-color imagery obtained from PROBA-V satellite. (right) Sea level anomaly retrieved along the transect, after removing the tide signature and other high-frequency features. The domains of plume waters and ocean waters, as seen from the satellite imagery, are highlighted in brown and blue, respectively. Adapted from Durand et al. (2017) 
the fresh plume waters (with high steric height) from the saltier ocean waters (with lower steric height).

\section{Conclusions}

Given the stakes of the coastal sea level variability with regard to the vulnerability of the shorelines of the major riverine and estuarine regions, in an era when the large ship-borne observational programs become less feasible in many countries, there is a need by the scientific community to invent the next generation of in situ observing networks. These networks will undoubtedly heavily rely on the development of cost-effective, research-quality, autonomous platforms. In order to discern between the various effects that can induce coastal sea level variability, including runoff, a comprehensive observing system, integrating not only runoff but also the other important variables, needs to be put in place in the coastal ocean.

The successful modeling of coastal sea level variability driven by river outflows remains challenging. This is due to the variety of processes involved (background regional circulation, tides, fine scale processes), that are all instrumental in the realistic representation of river plumes by numerical models, and that cover very broad spatial and temporal spectra. The numerical models need to be cross-scale enabled, encompass the continent - ocean continuum as a whole, and be numerically robust. Fortunately, the new generation of circulation models, in particular the tri-dimensional models implemented on varying-resolution grids, now allow an explicit resolution of the above processes, even over large regions. Just now, these tools are becoming mature enough, across several modeling teams around the world (e.g., Ye et al. 2016, Stanev et al. 2017, 2018, for the Chesapeake Bay, Black Sea, and Baltic Sea, respectively). Still the specific nature of river plumes, in particular the strong density gradients they induce, both horizontally and vertically, call for dedicated research to work out novel turbulent closure models, that can be adopted by the next generation of circulation models. From Sect. 4, it appears that the long timescales (interannual to interdecadal, including long-term changes) remain largely unaddressed in the literature. At a time when major river systems are suggesting significant long-term trends in the discharge in the past decades (Syed et al. 2010), and when the latest climate projections suggest significant changes in the global water cycle for the next century (Tao et al. 2014), it appears timely to address the variability of coastal sea level induced by runoff at these timescales.

As part of the global shoreline, the surroundings of large river mouths are particularly hot spots of human vulnerability to global change. It is now the right time to re-visit the topic of sea level variability driven by river discharge, building on the strong (though limited in several aspects) existing literature, taking advantage of the latest developments in numerical modeling and emerging observation technologies.

Acknowledgements We are thankful to Valérie Ballu and Stéphane Calmant for sharing the GNSS blanket dataset. Rachid Benshila carried out the Bay of Bengal passive tracer modeling experiment. We thank GRDC for providing discharge data on request. FD and JK were hosted by LIENSs-Université de La Rochelle, France during this work. CGP was supported by the Independent Research \& Development Program at Woods Hole Oceanographic Institution. JK was supported by Centre National d'Etudes Spatiales (CNES), FRANCE, and by the Embassy of France in Bangladesh. FP and FD were supported by the CNESTOSCA program via the BANDINO and AltiKest projects. MB was supported by the French research agency (Agence Nationale de la Recherche; ANR) under the DELTA project (ANR-17-CE03-0001). RMP was supported by NASA contract NNH16CT01C to AER. The in situ data presented in Fig. 6 were collected 
in the northern Bay of Bengal with support from the Ministry of Earth Sciences (MoES), Government of India. The authors thank all the project staff for their efforts in collecting these data.

\section{References}

Akhil VP, Durand F, Lengaigne M, VialardJ Keerthi MG, Gopalakrishna VV, Deltel C, Papa F, de Boyer Montegut C (2014) A modeling study of the processes of surface salinity seasonal cycle in the Bay of Bengal. J Geophys Res Oceans 119:3926-3947. https://doi.org/10.1002/2013jc009632

Akhil VP, Lengaigne M, Durand F, Vialard J, Chaitanya AVS, Keerthi MG, Gopalakrishna VV, Boutin J, de Boyer Montégut C (2016) Assessment of seasonal and year-to-year surface salinity signals retrieved from SMOS and Aquarius missions in the Bay of Bengal. Int J Remote Sens 37(5):1089-1114. https ://doi.org/10.1080/01431161.2016.1145362

Alsdorf DE, Rodriguez E, Lettenmaier DP (2007) Measuring surface water from space. Rev Geophys 45:124. https://doi.org/10.1029/2006rg000197

Aubrey DG, Emery KO, Uchipi E (1988) Changing coastal sea levels of South America and the Caribbean region from tide gauge records. Tectonophysics 154:269-284

Ballu V, Bouin MN, Siméoni P, Crawford WC, Calmant S, Boré JM et al (2011) Comparing the role of absolute sea-level rise and vertical tectonic motions in coastal flooding, Torres Islands (Vanuatu). Proc Natl Acad Sci USA 108(32):13019-13022

Becker M, Karpytchev M, Lennartz-Sassink S (2014) Long-term sea level trends: natural or anthropogenic? Geophys Res Lett 41:5571-5580

Becker M, Karpytchev M, Papa F (2019) Hotspots of relative sea level rise in the tropics, chapter 7. In: Vuruputur V, Sukhatme J, Murtugudde R, Roca R (eds) Tropical extremes: natural variability and trends: observations, modeling, and theoretical expectations. Elsevier, Amsterdam

Benshila R, Durand F, Masson S, Bourdallé-Badie R, de Boyer Montégut C, Papa F, Madec G (2014) The upper Bay of Bengal salinity structure in a high-resolution model. Ocean Model 74:36-52

Biancamaria S, Lettenmaier DP, Pavelsky TM (2016) The SWOT mission and its capabilities for land hydrology. Surv Geophys 37(2):307-337

Biancamaria S, Frappart F, Normandin C, Blarel F, Bourrel L, Aumont M, Azémar P, Vu P-L, Lubac B, Darrozes J (2017) Tonle Sap lake water storage change over 24 years from satellite observation and its link with Mekong River discharge and climate events. AGU fall meeting, 11-15 December 2017, New Orleans, LA, USA

Birol F, Fuller N, Lyard F, Cancet M, Niño F, Belebecque Fleury S, Toublanc F, Melet A, Saraceno M, Leger F (2017) Coastal applications from nadir altimetry: example of the X-TRACK regional products. Adv Space Res 59:936-953

Blaha JP (1984) Fluctuations of monthly sea level as related to the intensity of the gulf stream from key west to Norfolk. J Geophys Res 89(C5):8033-8042

Boutin J, Vergely JL, Marchand S, D’Amico F, Hasson A, Kolodziejczyk N, Reul N, Reverdin G, Vialard J (2018) New SMOS sea surface salinity with reduced systematic errors and improved variability. Remote Sens Environ 214:115-134. https://doi.org/10.1016/j.rse.2018.05.022

Calafat FM, Wahl T, Lindsten F, Williams J, Frajka-Williams E (2018) Coherent modulation of the sea-level annual cycle in the United States by Atlantic Rossby wave. Nat Commun 9:2571

Chaitanya AVS, Lengaigne M, Vialard J, Gopalakrishna VV, Durand F, Kranthikumar C, Amritash S, Suneel V, Papa F, Ravichandran M (2014) Fishermen-operated salinity measurements reveal a "river in the sea" flowing along the east coast of India. BAMS 95:1897-1908. https://doi.org/10.1175/ BAMS-D-12-00243.1

Chaitanya AVS, Durand F, Mathew S, Gopalakrishna VV, Papa F, Lengaigne M, Vialard J, Kranthikumar C, Venkatesan R (2015) Observed year-to-year sea surface salinity variability in the Bay of Bengal during the period 2009-2014. Ocean Dyn 65:173-186. https://doi.org/10.1007/s10236-014-0802-X

Chandanpurkar HA, Reager JT, Famiglietti JS, Syed TH (2017) Satellite- and reanalysis-based mass balance estimates of global continental discharge (1993-2015). J Clim 30:8481-8495. https://doi.org/10.1175/ JCLI-D-16-0708.1

Chelton DB, Davis RE (1982) Monthly mean sea-level variability along the west coast of North America. J Phys Oceanogr 12:757-784

Chelton DB, Enfield DB (1986) Ocean signals in tide gauge records. J Geophys Res 91(B9):9081-9098

Cipollini P, et al (2010) The role of altimetry in coastal observing systems. In: Hall J, Harrison DE, Stammer D(eds) Proceedings of OceanObS09: sustained ocean observations and information for society (vol 2), Venice, Italy, 21-25 September 2009. ESA Publication WPP-306 
Clark EA, Sheffield J, Van Vliet MTH, Nijssen B, Lettenmaier DP (2015) Continental runoff into the Oceans (1950-2008). J Hydrometeorol 16:1502-1520. https://doi.org/10.1175/jhm-d-14-0183.1

Coles VJ, Brooks MT, Hopkins J, Stukel MR, Yager PL, Hood RR (2013) The pathways and properties of the Amazon River Plume in the tropical North Atlantic Ocean. J Geophys Res Oceans 118:68946913. https://doi.org/10.1002/2013jc008981

da Silva CE, Castelao RM (2018) Mississippi River plume variability in the Gulf of Mexico from SMAP and MODIS-Aqua observations. J Geophys Res Oceans 123:6620-6638. https://doi.org/10.1029/2018J C014159

Dai A (2016) Historical and future changes in streamflow and continental runoff: a review. In: Tang Q, Oki $\mathrm{T}$ (eds) Terrestrial water cycle and climate change: natural and human-induced impacts. Geophysical monograph 221. AGU, Wiley, Hoboken, pp 17-37. https://doi.org/10.1002/9781118971772

Dai A, Trenberth KE (2002) Estimates of freshwater discharge from continents: latitudinal and seasonal variations. J Hydrometeorol 3(6):660-687

Dai A, Qian T, Trenberth KE (2009) Changes in continental freshwater discharge from 1948 to 2004. J Clim 22(10):2773-2792. https://doi.org/10.1175/2008jcli2592.1

Do HX, Gudmundsson L, Leonard M, Westra S (2018) The global streamflow indices and metadata archive (GSIM)-Part 1 : The production of a daily streamflow archive and metadata. Earth Syst Sci Data 10:765-785. https://doi.org/10.5194/essd-10-765-2018

Dobslaw H, Thomas M (2007) Impact of river run-off on global ocean mass redistribution. Geophys J Int 168:527-532

Dufau C, Orsztynowicz M, Dibarboure G, Morrow R, Le Traon P-Y (2016) Mesoscale resolution capability of altimetry: present and future. J Geophys Res Oceans 121:4910-4927

Durand F, Papa F, Rahman A, Bala SK (2011) Impact of Ganges-Brahmaputra interannual discharge variations on Bay of Bengal salinity and temperature during the 1992-99 period. J Earth Syst Sc. 120(5):859-872

Durand F, Calmant S, Calzas M, Ballu V, Testut L, Valty P, Krien Y, Bonnefond P, Papa F (2017) Geodetic survey of the freshwater front of the Ganges-Brahmaputra freshwater plume in the northern Bay of Bengal from CalNaGeo GNSS device. OSTST2017, Miami, USA, Oct 2017

Ekman M (1996) A consistent map of the postglacial uplift of Fennoscandia. Terra Nova 8:158-165. https:// doi.org/10.1111/j.1365-3121.1996.tb00739.x

Emery KO, Aubrey DG (1991) Sea levels, land levels, and tide gauges. Springer, New York, p 237

Fekete B, Vörösmarty CJ, Grabs W (2000) Report no. 22: global composite runoff fields based on observed discharge and simulated water balances. Global Runoff Data Centre/Federal Institute of Hydrology (BfG) Rep., 108 pp

Fekete B, Robarts RD, Kumagai M, Nachtnebel HP, Odada E, Zhulidov AV (2015) Time for in situ renaissance. Science 349(6249):685-686. https://doi.org/10.1126/science.aac7358

Fong D, Geyer WR (2002) The alongshore transport of freshwater in a surface trapped river plume. J Phys Oceanogr 32:957-972

Fong D, Geyer WR, Signell R (1997) The wind-forced response on a buoyant coastal current: observations of the western Gulf of Maine. J Mar Syst 12:69-81

Fournier S, Vandemark D, Gaultier L, Lee T, Jonsson B, Gierach MM (2017a) Interannual variation in offshore advection of Amazon-Orinoco plume waters: observations, forcing mechanisms, and impacts. J Geophys Res : Oceans 122:8966-8982. https://doi.org/10.1002/2017JC013103

Fournier S, Vialard J, Lengaigne M, Lee T, Gierach MM, Chaitanya AVS (2017b) Modulation of the Ganges-Brahmaputra river plume by the Indian Ocean dipole and eddies inferred from satellite observations. J Geophys Res: Oceans 122:9591-9604. https://doi.org/10.1002/2017JC013333

Frappart F, Papa F, Marieu V, Malbeteau Y, Jordy F, Calmant S, Durand F, Bala S (2015) Preliminary assessment of SARAL/ALTIKA observations over the Ganges-Brahmaputra and Irrawaddy rivers. Mar Geodesy 38:568-580. https://doi.org/10.1080/01490419.2014.990591

Garvine RW (1999) Penetration of buoyant coastal discharge onto the continental shelf: a numerical model experiment. J Phys Oceanogr 29:1892-1909

Garvine RW (2001) The impact of model configuration in studies of buoyant coastal discharge. J Mar Res 59:193-225

Geyer WR (1995) Tide-induced mixing in the Amazon frontal zone. J Geophys Res 100(C2):2341-2353. https://doi.org/10.1029/94jc02543

Geyer WR, Kineke GC (1995) Observations of currents and water properties in the Amazon frontal zone. J Geophys Res 100(C2):2321-2339. https://doi.org/10.1029/94jc02657

Gill AE, Niller PP (1973) The theory of the seasonal variability in the ocean. Deep Sea Res 20(2):141-177. https://doi.org/10.1016/0011-7471(73)90049-1 
Gómeze-Enri J, Cipollini P, Passaro M, Vignudelli S, Tejedor B, Coca J (2016) Coastal altimetry products in the strait of Gibralar. IEEE T Geosci Remote 54(9):5455-5466

Gough WA, Robinson CA (2000) Sea-level variation in Hudson Bay, Canada, from Tide-Gauge data. Arct Antarct Alp Res 32(3):331-335

GRDC (2014) Global freshwater fluxes into the world oceans/online provided by global runoff data centre, 2014 edn. Federal Institute of Hydrology (BfG), Koblenz

GRDC (2018) Long-Term statistics and annual characteristics of GRDC timeseries data/online provided by the global runoff data centre of WMO. Federal Institute of Hydrology (BfG), Koblenz. Accessed 29 Nov 2018

Gudmundsson L, Do HX, Leonard M, Westra S (2018) The global streamflow indices and metadata archive (GSIM) - Part 2: quality control, time-series indices and homogeneity assessment. Earth Syst Sci Data 10:787-804. https://doi.org/10.5194/essd-10-787-2018

Guo X, Valle-Levinson A (2007) Tidal effects on estuarine circulation and outflow plume in the Chesapeake Bay. Cont Shelf Res 27(1):20-42. https://doi.org/10.1016/j.csr.2006.08.009

Han G (2002) Interannual sea-level variations in the Scotia-Maine region in the 1990s. Can J Remote Sens 28(4):581-587

Han W, Webster PJ (2002) Forcing mechanisms of sea level interannual variability in the Bay of Bengal. J Phys Oceanogr 32:216-239

Hong BG, Sturges W, Clarke AJ (2000) Sea level on the U.S. east coast: decadal variability caused by open ocean wind-curl forcing. J Phys Oceanogr 29:2088-2098. https://doi. org/10.1175/1520-0485(2000)030

Hordoir R, Nguyen KD, Polcher J (2006) Simulating tropical river plumes, a set of parametrizations based on macroscale data: a test case in the Mekong Delta region. J Geophys Res 111:C09036. https://doi.org/10.1029/2005jc003392

Horner-Devine AR, Hetland RD, MacDonal DG (2015) Mixing and transport in coastal river plumes. Annu Rev Fluid Mech 47:569-594

HYBAM (2018) Contrôles géodynamique, hydrologique et biogéochimique de l'érosion/altération et des transferts de matière dans les bassins de l'Amazone, de l'Orénoque et du Congo. http://www.orehybam.org. Accessed 29 Nov 2018

Jian J, Webster PJ, Hoyos CD (2009) Large-scale controls on Ganges and Brahmaputra river discharge on intraseasonal and seasonal time scales. Q J R Meteorol Soc 135:353-370. https://doi. org/10.1002/qj.384

Kärnä T, Baptista AM, Lopez JE, Turner PJ, McNeil C, Sanford TB (2015) Numerical modeling of circulation in high-energy estuaries: a Columbia River estuary benchmark. Ocean Model 88:54-71. https://doi.org/10.1016/j.ocemod.2015.01.001

Karpytchev M, Ballu V, Krien Y, Becker M, Goodbred S, Spada G, Calmant S, Shum CK, Khan Z (2018) Contributions of a strengthened early holocene monsoon and sediment loading to presentday subsidence of the Ganges-Brahmaputra delta. Geophys Res Lett 45(3):1433-1442. https://doi. org/10.1002/2017GL076388

Krien Y, Mayet C, Testut L, Durand F, Tazkia AR, Islam AKMS, Gopalakrishna VV, Becker M, Calmant S, Papa F, Ballu V, Shum CK, Khan ZH (2016) Improved bathymetric dataset and tidal model for the head Bay of Bengal. Marine Geodesy 39:422-438. https://doi.org/10.1080/01490 419.2016.1227405

Laiz I, Gómez-Enri J, Tejedor B, Aboitiz A, Villares P (2013) Seasonal sea level variations in the gulf of Cadiz continental shelf from in situ measurements and satellite altimetry. Cont Shelf Res 53:7788. https://doi.org/10.1016/j.csr.2012.12.008

Laiz I, Ferrer L, Plomaritis TA, Charria G (2014) Effect of river runoff on sea level from in situ measurements and numerical models in the Bay of Biscay. Deep-Sea Res II 106:49-67. https://doi. org/10.1016/j.dsr2.2013.12.013i

Lammers RB, Shiklomanov AI, Vörosmarty CJ, Fekete BM, Peterson BJ (2001) Assessment of contemporary Arctic river runoff based on observational discharge records. J Geophys Res 106:33213334. https://doi.org/10.1029/2000jd900444

Lentz SJ, Limeburner R (1995) The Amazon River Plume during AMASSEDS: spatial characteristics and salinity variability. J of Geophys Res 100(C2):2355. https://doi.org/10.1029/94jc01411

Li M, Zhong L, Boicourt WC (2005) Simulations of Chesapeake Bay estuary: sensitivity to turbulence mixing parameterizations and comparison with observations. J Geophys Res 110(C12004)

Lorbacher KS, Marsland J, Church JA, Griffies SM, Stammer D (2012) Rapid barotropic sea level ris from ice sheet melting. J Geophys Res. https://doi.org/10.1029/2011jc007733

Marcos M, Wöppelmann G, Matthews A et al (2019) Coastal sea level and related fields from existing observing systems. Surv Geophys 10:15-20. https://doi.org/10.1007/s10712-019-09513-3 
McCreary JP, Zhang S, Shetye SR (1997) Coastal circulation driven by river outflow in a variable-density 11/2-layer model. J Geophys Res 102:15535-15554

Meade RH, Emery KO (1971) Sea level as affected by river runoff, eastern United States. Science 173:425-428

Muller-Karger FE, McClain CR, Richardson PL (1988) The dispersal of the Amazon's water. Nature 333(6168):56-59. https://doi.org/10.1038/333056a0

Neetu S, Lengaigne M, Vincent EM, Vialard J, Madec G, Samson G, Ramesh Kumar MR, Durand F (2012) Influence of upper-ocean stratification on tropical cyclones-induced surface cooling in the Bay of Bengal. J Geophys Res 117:C12020

Neumann B, Vafeidis AT, Zimmermann J, Nicholls RJ (2015) Future coastal population growth and exposure to sea-level rise and coastal flooding — a global assessment. PLoS ONE 10(3):e0118571. https:// doi.org/10.1371/journal.pone.0118571

Nittrouer CA, DeMaster DJ, Figueiredo AG, Rine JM (1991) AmasSeds: an interdisciplinary investigation of a complex coastal environment. Oceanography 4(1):3-7. https://doi.org/10.5670/oceanog.1991.14

Nof D (2005) The momentum imbalance paradox revisited. J Phys Oceanogr 35:1928-1939

Nof D, Pichevin T (2001) The ballooning of outflows. J Phys Oceanogr 31:3045-3058

Palma ED, Matano RP (2012) A numerical study of the Magellan Plume. J Geophys Res 117:C05041. https ://doi.org/10.1029/2011jc007750

Papa F, Bala SK, Kumar Pandey R, Durand F, Gopalakrishna VV, Rahman A, Rossow WB (2012a) GangaBrahmaputra river discharge from Jason-2 radar altimetry: an update to the long-term satellite-derived estimates of continental freshwater forcing flux into the Bay of Bengal. J Geophys Res 117:C11021. https://doi.org/10.1029/2012jc008158

Papa F, Biancamaria S, Lion C, Rossow WB (2012b) Uncertainties in mean river discharge estimates associated with satellite altimeters temporal sampling intervals: a case study for the annual peak flow in the context of the future SWOT hydrology mission. IEEE Geosci Remote Sens Lett 9(4):569-573. https://doi.org/10.1109/lgrs.2011.2174958

Passaro M, Cipollini P, Benveniste J (2015) Annual sea level variability of the coastal ocean: the Baltic SeaNorth Sea transition zone. J Geophys Res Oceans 120:3061-3078

Peralta-Ferriz C, Morison J (2010) Understanding the annual cycle of the Arctic Ocean bottom pressure. Geophys Res Lett 37:L10603. https://doi.org/10.1029/2010g1042827

Phien-wej N, Giao PH, Nutalaya P (2006) Land subsidence in Bangkok. Thailand. Eng Geol 82(4):187-201. https://doi.org/10.1016/j.enggeo.2005

Pichevin T, Nof D (1997) The momentum imbalance paradox. Tellus 49:298-319

Piecuch CG, Bittermann K, Kemp AC, Ponte RM, Little CM, Engelhart SE, Lentz SJ (2018) River-discharge effects on United States Atlantic and Gulf coast sea-level changes. Proc Natl Acad Sci 115(30):7729-7734. https://doi.org/10.1073/pnas.1805428115

Piecuch CG, Calafat FM, Dangendorf S, Jordà G (2019) The ability of barotropic models to simulate historical mean sea level changes from coastal tide gauge data. https://doi.org/10.1007/s10712-019-09537-9

Ponte RM (1993) Variability in a homogeneous global ocean forced by barometric pressure. Dyn Atmos Oceans 18:209-234

Ponte RM (2006) Oceanic response to surface loading effects neglected in volume-conserving models. J Phys Oceanogr 36:426-434

Prigent C, Lettenmaier DP, Aires F, Papa F (2016) Towards a high resolution monitoring of continental surface water extent and dynamics, at global scale: from GIEMS (global inundation extent from multisatellites) to SWOT (surface water ocean topography). Surv Geophys 37(2):339-355. https://doi. org/10.1007/s10712-015-9339-x

Proshutinsky A, Ashik IM, Dvorkin EN, Hakkinen S, Krishfield RA, Peltier WR (2004) Secular sea level change in the Russian sector of the Arctic Ocean. J Geophys Res 109:C03042

Reul N, Quilfen Y, Chapron B, Fournier S, Kudryavtsev V, Sabia R (2014) Multisensor observations of the Amazon-Orinoco river plume interactions with hurricanes. J Geophys Res Oceans 119:8271-8295. https://doi.org/10.1002/2014jc010107

Roden GI (1960) On the nonseasonal variations in sea level along the west coast of North America. J Geophys Res 65(9):2809-2826

Rodolfo KS, Siringan FP (2006) Global sea-level rise is recognised, but flooding from anthropogenic land subsidence is ignored around northern Manila Bay, Philippines. Disasters 30(1):118-139

Royer TC (1979) On the effect of precipitation and runoff on coastal circulation in the Gulf of Alaska. J Phys Oceanogr 9:555-563

Ruiz Etcheverry LA, Saraceno M, Piola AR, Valladeau G, Moeller OO (2015) A comparison of the annual cycle of sea level in coastal areas from gridded satellite altimetry and tide gauges. Cont Shelf Res 92:87-97 
Santamaria-Gomez A, Gravelle M, Dangendorf S, Marcos M, Spada G, Woppelmann G (2017) Uncertainty of the 20th century sea-level rise due to vertical land motion errors. Earth Planet Sci Lett 473:24-32

Saramul S, Ezer T (2014) Spatial variations of sea level along the coast of Thailand: impacts of extreme land subsidence, earthquakes and the seasonal monsoon. Global Planet Change 122:70-81

Sengupta D, Bharath Raj GN, Ravichandran M, Sree Lekha J, Papa F (2016) Near-surface salinity and stratification in the north Bay of Bengal from moored observations. Geophys Res Lett 43:4448-4456. https://doi.org/10.1002/2016GL068339

Shankar D, Vinayachandran P, Unnikrishnan AS (2002) The monsoon currents in the north Indian Ocean. Prog Oceanogr 52:63-120

Shankar D, Gandhi Aparna Saieesh, McCreary JP, Suresh I, Neetu S, Durand F, Shenoi SSC, Al Saafani MA (2010) Minima of interannual sea-level variability in the Indian Ocean. Progress in Oceanography 83:225-241. https://doi.org/10.1016/j.pocean.2009.10.002

Sherin VR, Durand F, Gopalakrishna VV, Anuvinda S, Chaitanya AVS, Bourdalle-Badie R, Papa F (2018) Signature of Indian Ocean dipole on the western boundary current of the Bay of Bengal revealed from 27 years of repeated in situ observations. DSR-I 136:91-106. https://doi.org/10.1016/j. dsr.2018.04.002

Shiklomanov AI, Lammers RB, Vorosmarty CJ (2002) Widespread decline in hydrological monitoring threatens Pan-Arctic Research. EOS Trans Am Geophys Union 83:13. https://doi.org/10.1029/2002e o000007

Simpson JH (1997) Physical processes in the ROFI regime. J Mar Syst 12(1-4):3-15. https://doi. org/10.1016/s0924-7963(96)00085-1

Sree Lekha J, Buckley JM, Tandon A, Sengupta D (2018) Subseasonal dispersal of freshwater in the northern Bay of Bengal in the 2013 summer monsoon season. J. Geophys Res Oceans 123:6330-6348. https://doi.org/10.1029/2018jc014181

Stammer D (2010) Reply to comment by J. F. R. Gower on "Response of the global ocean to Greenland and Antarctic ice melting. J Geophys Res 115:C10010. https://doi.org/10.1029/2010jc006457

Stanev EV, Grashorn S, Zhang Y (2017) Cascading ocean basins: numerical simulations of the circulation and interbasin exchange in the Azov-Black-Marmara-Mediterranean Seas system. Ocean Dyn 67:1003-1025. https://doi.org/10.1007/s10236-017-1071-2

Stanev EV, Pein J, Grashorn S, Zhang Y, Schrum C (2018) Dynamics of the Baltic Sea straits via numerical simulation of exchange flows. Ocean Model 131:40-58

Suzuki T, Yamazaki D, Tsujino H, Komuro Y, Nakano H, Urakawa S (2018) A dataset of continental river discharge based on JRA-55 for use in a global ocean circulation model. J Oceanogr 74:421-429. https://doi.org/10.1007/s10872-017-0458-5

Svendsen PL, Andersen OB, Nielsen AA (2016) Stable reconstruction of Arctic sea level for the 1950-2010 period. J Geophys Res Oceans 121:5697-5710

Syed TH, Famiglietti JS, Chambers DP, Willis JK, Hilburn K (2010) Satellite-based global-ocean mass balance estimates of interannual variability and emerging trends in continental freshwater discharge. PNAS 107(42):7916-17921. https://doi.org/10.1073/pnas.1003292107

Tao B, Tian H, Ren W, Yang J, Yang Q, He R, Cai W, Lohrenz S (2014) Increasing Mississippi river discharge throughout the 21 st century influenced by changes in climate, land use, and atmospheric CO2. Geophys Res Lett 41:4978-4986. https://doi.org/10.1002/2014g1060361

Tarpanelli A, Amarnath G, Brocca L, Massari C, Moramarco T (2017) Discharge estimation and forecasting by MODIS and altimetry data in Niger-Benue River. Remot Sens Env 195:96-106. https://doi. org/10.1016/j.rse.2017.04.015

Tarpanelli A, Santi E, Tourian MJ, Filippucci P, Amarnath G, Brocca L (2018) Daily river discharge estimates by merging satellite optical sensors and radar altimetry through artificial neural network. IEEE Trans Geosci Remote Sens 10:15-20. https://doi.org/10.1109/tgrs.2018.2854625

Torres RR, Tsimplis MN (2012) Seasonal sea level cycle in the Caribbean Sea. J Geophys Res 117:C07011

Trenberth KE, Smith L, Qian T, Dai A, Fasullo J (2007) Estimates of the global water budget and its annual cycle using observational and model data. J Hydrometeorol 8:758-769. https://doi.org/10.1175/ JHM600.1

Tsimplis MN, Woodworth PL (1994) The global distribution of the seasonal sea level cycle calculated from coastal tide gauge data. J Geophys Res 99(C8):16031-16039

Vignudelli S, Kostianoy A, Cipollini P, Benveniste J (2011) Coastal altimetry. Springer, Berlin, p 565

Vinogradov SV, Ponte RM (2011) Low-frequency variability in coastal sea level from tide gauges and altimetry. J Geophys Res 116:C07006

Volkov DL, Johns WE, Belonenko TV (2016) Dynamic response of the Black Sea elevation to intraseasonal fluctuations of the Mediterranean sea level. Geophys Res Lett 43:283-290. https://doi. org/10.1002/2015g1066876 
Walker ND, Gargion GF, Rouse LJ, Biggs DC (1994) The great flood of summer 1993: Mississippi river discharge studied. EOS Trans Am Geophys Union 75:36

Wijesekera HW et al (2016) ASIRI: an ocean-atmosphere initiative for Bay of Bengal. Bull Am Meteor Soc 97(10):1859-1884. https://doi.org/10.1175/BAMS-D-14-00197.1

Wu H, Zhu J, Shen J, Wang H (2011) Tidal modulation on the Changjiang River plume in summer. J Geophys Res 116:08017. https://doi.org/10.1029/2011JC007209

Wu H, Shen J, Zhu J, Zhang J, Li L (2014) Characteristics of the Changjiang plume and its extension along the Jiangsu Coast. Cont Shelf Res 76:108-123. https://doi.org/10.1016/j.csr.2014.01.007

$\mathrm{Xu}$ K, Milliman JD (2009) Seasonal variations of sediment discharge from the Yangtze River before and after impoundment of the Three Gorges Dam. Geomorphology 104:276-283. https://doi. org/10.1016/j.geomorph.2008.09.004

Yankovsky AE (2000) The cyclonic turning and propagation of buoyant coastal discharge along the shelf. J Mar Res 58:585-607

Ye F, Zhang YJ, Friedrichs MAM, Wang HV, Irby ID, Shen J, Wang Z (2016) A 3D, cross-scale, baroclinic model with implicit vertical transport for the Upper Chesapeake Bay and its tributaries. Ocean Model 107:82-96. https://doi.org/10.1016/j.ocemod.2016.10.004

Publisher's Note Springer Nature remains neutral with regard to jurisdictional claims in published maps and institutional affiliations. 